\title{
Water Quality Assessment in Karaboğaz Stream Basin (Turkey) from a Multi-Statistical Perspective
}

\author{
Arzu Aydın Uncumusaoğlu ${ }^{1 *}$, Ekrem Mutlu ${ }^{2}$ \\ ${ }^{1}$ Giresun University, Faculty of Engineering, Departments of Environmental Engineering, 28200, Giresun, \\ Turkey, Orcid: 0000-0002-9676-7737 \\ ${ }^{2}$ Kastamonu University, Faculty of Fisheries, Departments of Aquaculture, 37150 Kastamonu, \\ Turkey, Orcid: 0000-0002-6000-245X
}

Received: 1 December 2020

Accepted: 28 January 2021

\begin{abstract}
This study aims to evaluate the spatial and temporal changes in water quality of Karaboğaz Stream using statistical methods, to determine the main pollutant sources and to demonstrate the water quality classes. Water-quality data were obtained monthly (November 2016-October 2017) from 10 stations and considering 28 parameters. Temporal and spatial variations of Stream surface water quality were analyzed using multivariate statistical techniques on datasets, including agglomerative hierarchical clustering analysis (HCA) and principal component analysis (PCA). The analysis refers to the four main components responsible for the data structure and accounts for $87.41 \%$ of the total variance of the dataset. The root of these main components is generally related to the point source pollution (anthropogenic), nonpoint source pollution (agricultural activities) and natural processes (climate, soil and rock erosion). The temporal analysis of the water quality with HCA indicated that autumn is different from the other seasons. This study presents the practicality of various statistical methods in assessing and interpreting water-quality data to monitor and increase the management efficiency. When designing the most appropriate action plans for managers to control pollution, clearer, understandable information can be achieved using these methods and interpreting raw data.
\end{abstract}

Keywords: water quality, multivariate statistical analysis, principal component analysis (PCA), hierarchical clustering analysis (HCA), temporal-spatial variations

*e-mail: arzu.a.uncumusaoglu@gmail.com 


\section{Introduction}

Main text paragraph. Water is one of the most important and abundant compounds of the world's ecosystems. All living organisms in the world require freshwater to survive and for all their metabolic activities [1]. Today, a number of complex factors such as population growth, urbanization, improper agricultural practices and pollution have made it difficult for water to be found, and to be brought to settlements. This has become one of the main problems of humankind. Inadequate drinking water can lead to devastating consequences, such as increased health problems, social upheaval or even war [2]. Therefore, lists of countries experiencing water stress have been established in line with the studies executed in the Organization for Economic Cooperation and Development countries. Thus, many countries have used rainfalls drained from the roof to solve the water problem for thousands of years [3]. High-quality drinking water is now a serious concern. It has become an increasingly serious problem in recent years owing to the pollution of rivers, which is one of the freshwater resources, rapid industrialization, urbanization, population growth and global climate change [4]. Because river basins are generally used as drinking and irrigation water, they form fertile soil around them. These basins constitute positive living conditions for humans due to their availability in agriculture, transport, industry, and animal breeding, and are therefore regions with high population density [5]. One of the activities that consume the most water in these regions is agricultural irrigation, which accounts for $\sim 70 \%$ of the total consumption.

Given the fact that the pollution and the change of quality of countless rivers in the world owing to anthropogenic activities, the availability, and quality of freshwater constitute the problem of our century and future [6-8]. These activities continue with increasing amounts of point and non-point pollutants being discharged into the water, which is the receiving medium [9]. Point sources can be defined as the direct transfer of pollution from source to the receiving medium, i.e. water, via pipes and other sources. For example, the municipal sewer releases the wastewater from the sewage treatment facility, or the plant is discharged directly to the receiving medium, i.e. to the water. In contrast, non-point sources that depend on the precipitation flow from different polluting sources, such as agricultural or urban areas, to surface water or drains to groundwater [10, 11].

Rivers are affected by pollution, which is resulted from anthropogenic, industrial and agricultural activities of the settlements in the near vicinity, owing to excessive access from both point and non-point sources. In addition to the interactions of pollutants, climate factors, sediments, hydrological properties and water metabolisms together with spatial and temporal variations determine the quality of river water $[12,13]$.

Long-term water-quality research and monitoring programs are essential for reliable water use. These are sufficient to have a detailed knowledge of river hydrochemistry and pollution. However, they result in large and complex datasets comprising a large number of physicochemical parameters that increase the workload and operating costs and usually produce large datasets that are difficult to interpret [14]. In addition, the collection and classification of large amounts of data present time and cost challenges both in terms of developing effective management strategies for water resources and monitoring activities in the future [15].

Recently, in various monitoring areas, multivariate statistical and computational methods, such as one-way analysis of variance (ANOVA), Pearson's correlation, hierarchical agglomerative cluster analysis (HCA), principal component analysis (PCA), factor analysis (FA) and discriminant analysis (DA) have been developed for their large number of spatial and temporal data processing capabilities to better understand water quality and ecological status, to distinguish large datasets to meaningful intervals, to obtain useful information, to identify relations between relevant data and to evaluate the results $[5,16]$. These analyses and techniques provide a valuable tool for a quick solution to pollution problems for reliable management of water resources, a better understanding of water quality, recognition of possible factors/sources affecting water systems, identification of sources of pollution and grouping of similar monitoring stations by clusters with similar characteristics [17-19]. In addition, multivariate statistical techniques have been used for issues such as risk assessment in wastewater management, assessment of water recycling strategies and assessment of groundwater hydrology and chemistry [20].

This study was conducted monthly in Karaboğaz Stream with 28 parameters in 10 stations. It is aimed to determine the water-quality class of the stream using multivariate statistical techniques to obtain information about the similarities or differences between sampling areas from a broad data matrix obtained during the monitoring program and by achieving goals, such as the identification of spatial and temporal variables, establishment of water-quality variables responsible for environmental impacts, investigation of possible effects of hidden factors explaining the structure of the database and examination of impacts of possible sources (point, non-point and natural) on the water-quality parameters according to the world health organization (WHO) and Turkey's surface water-quality regulation of inland above ground water resources water-quality classes (SWQR) [21, 22]. 


\section{Materials and Methods}

\section{Sample Location and Sampling}

The Karaboğaz Stream located at the Divriği district of Sivas (East of Central Anatolia) province is $86 \mathrm{~km}$ away from the city central and $18 \mathrm{~km}$ away from the district of Divriği. This Stream originates in Çengelli Mountain at $2596 \mathrm{~m}$ elevation in the Central Anatolia Region and flows through the borders of Kışla, Karakuzulu, Bahçeli, Kekliktepe, Karaağaç and Şahin villages of İmranlı District; joins with Çaltı Stream and reaches the Firat River (Euphrates). It is at a $1600 \mathrm{~m}$ elevation from the sea level. Farmers irrigate gardens, fields, with water coming from the stream. The valley fed by Karaboğaz Stream is home to animal species on the faces such as wild goats, Anatolian pieces, lynx, and striped hyena come to life in this watershed under threat of extinction. Karaboğaz Stream is the spawning ground for tens of fish species living in the Firat River. In terms of Partridge population, Karaboğaz stream basin is the second largest region of Turkey [23].

\section{Monitoring Sites}

Water samples were taken from 10 stations (Fig.1), which were determined by considering residential places located on Stream's path and agriculture or fruit gardens, which might be non-point pollution sources. Sampling was conducted once a month and in one year (November 2016-October 2017) to determine spatial and temporal changes in water quality [24].

\section{Determination of Physicochemical Parameters}

In the study area wherein four seasons were experienced owing to its geographical location, water samples were subjected to physical and chemical analyses and their data were seasonally evaluated. The physical parameters of water quality, such as dissolved oxygen (DO), electrical conductivity (EC), salinity and water temperature (WT), were measured using the multiparameter YSI 556 MPS model in the field. Biological oxygen demand $\left(\mathrm{BOD}_{5}\right)$, chemical oxygen demand (COD), total alkalinity (TA), total hardness (TH), nitrite nitrogen $\left(\mathrm{NO}_{2}^{-}-\mathrm{N}\right)$, nitrate nitrogen $\left(\mathrm{NO}_{3}^{-}-\mathrm{N}\right)$, ammonium nitrogen $\left(\mathrm{NH}_{4}^{+}-\mathrm{N}\right)$, sulfite $\left(\mathrm{SO}_{3}{ }^{2-}\right)$, sulphate $\left(\mathrm{SO}_{4}{ }^{2-}\right)$, potassium $\left(\mathrm{K}^{+}\right)$, chloride $\left(\mathrm{Cl}^{-}\right)$and phosphatephosphorus $\left(\mathrm{PO}_{4}^{3-} \mathrm{P}\right)$ were analysed in the laboratory using the standard method with spectrophotometer [25, 26]. Titration was performed with sulfuric acid for TA and with EDTA for TH; the results are shown as $\mathrm{CaCO}_{3}$ $\mathrm{mg} \mathrm{L}^{-1}$. Whatman membrane filters were used for solid matter suspended in water (SS) analysis. The water was passed through the filter paper and then held at $103^{\circ} \mathrm{C}$ for $24 \mathrm{~h}$; the weight difference was then calculated [27]. Magnesium $\left(\mathrm{Mg}^{2+}\right)$, calcium $\left(\mathrm{Ca}^{2+}\right)$ and sodium $\left(\mathrm{Na}^{+}\right)$ was measured using a direct flame photometer. Using ICP-MS instrument in water samples, cadmium $\left(\mathrm{Cd}^{2+}\right)$, nickel $\left(\mathrm{Ni}^{2+}\right)$, copper $\left(\mathrm{Cu}^{2+}\right)$, lead $\left(\mathrm{Pb}^{2+}\right)$, iron $\left(\mathrm{Fe}^{2+}\right)$ and zinc $\left(\mathrm{Zn}^{2+}\right)$ heavy metal analyses were performed.

To determine water-quality classes, assessments have been performed using general chemical and physicochemical parameters based on the quality and class standards of, primarily, WHO (World Health

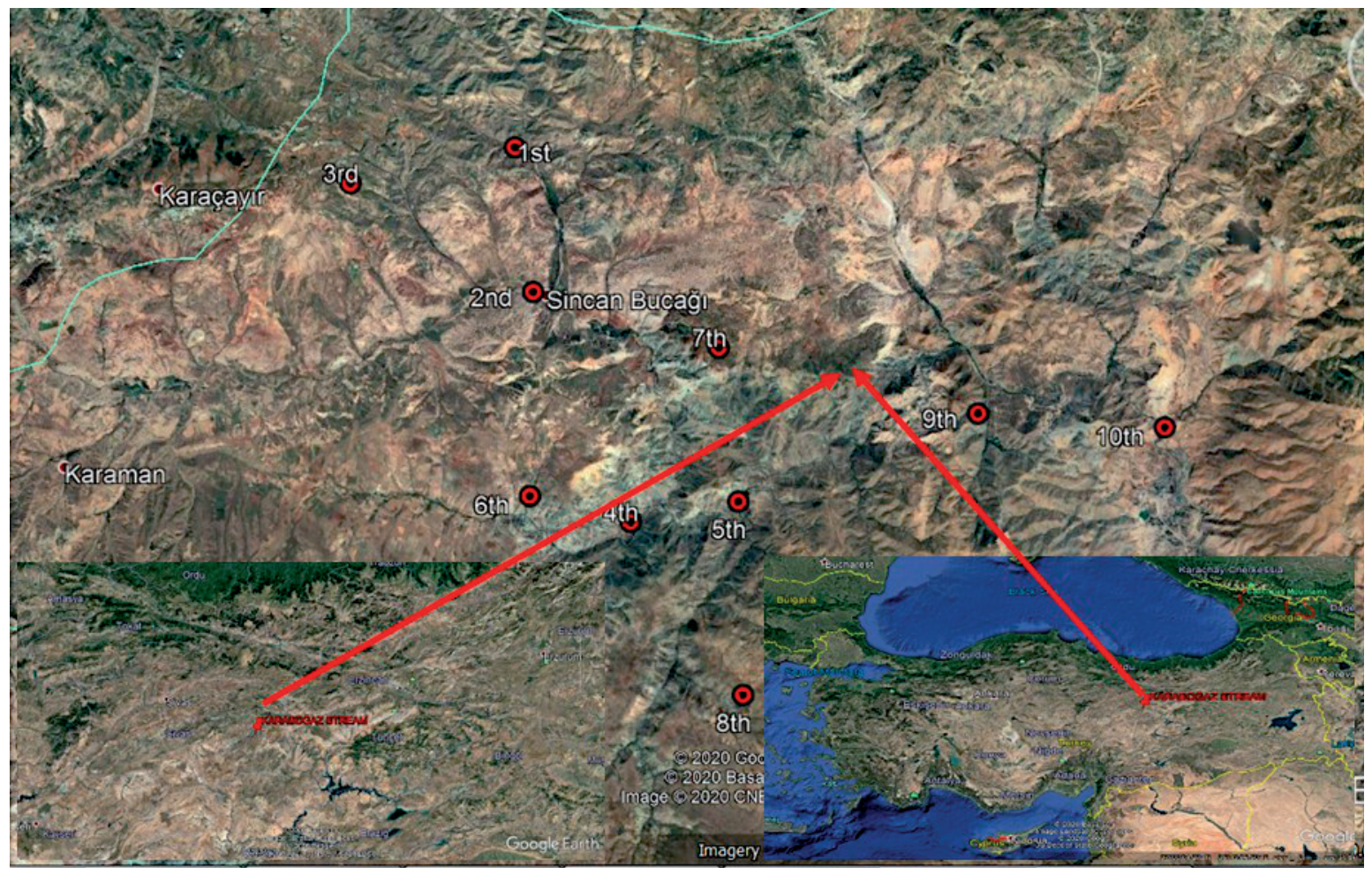

Fig. 1. Karaboğaz Stream basin and water quality stations (adapted from Google Earth). 
Organization) and Turkey's surface water-quality regulation of inland surface water resources. [21, 22].

\section{Data Treatment and Multivariate Statistical Analysis}

Using multivariate statistical methods, it is ensured that a wide variety and excessive amount of data are easier to understand and interpret [28]. For this purpose, one-way variance analysis (ANOVA), Pearson correlation, HCA and principal component analysis/ FA were performed. One-way variance (ANOVA) analysis was conducted to investigate whether there was a difference between measurements of the same observations at different times or spaces from any variable perspective [29]. In this study, Tukey's multiple range tests were used to determine whether there is a significant difference between the mean values of stations and seasons. Correlation coefficients are coefficients that provide information about the strength/ grade of the relation between two variables. Within this framework, a number of frequently used correlation coefficients such as Pearson, Spearman, Cramer V, Phi, provide information about the strength of the relation between two variables [29]. Because of the non-uniform distribution of the measured water-quality parameters, the correlation between variables is calculated by the nonparametric Pearson correlation (r) coefficient [30]. The correlation coefficient is a value ranging from -1 to 1 and measures the degree of the linear relation between the two variables. If $\mathrm{R}$ is close to -1 , a strong negative linear relation exists between these variables and if it is close to +1 , a strong positive linear relation exists [30].

It is expected that the clusters to be obtained because of the clustering analysis will be as homogeneous as possible but heterogeneous among themselves [29]. HCA is a combination of techniques used to classify large datasets into clusters or similarities based on differences of [24]. Clustering is performed in two ways as hierarchical clustering and non-hierarchical clustering. The most widely used method is hierarchical clustering [29-32]. The distance between the samples is used as a measure of similarity in the hierarchical agglomerative clustering method. The dendrogram provides a visual summary of the groups and their proximity to these groups. HCA was used to observe the clustering of Karaboğaz Stream water-quality dataset. When this analysis was performed, Ward's method was regarded as the measure of similarity [33].

FA is a collection of methods that are often used in situations wherein it is questioned if a large number of variables can actually be expressed by a few basic variables. Besides, it is intended to demonstrate a small number of new variables that are interpretive, independent and with less information loss from a large number of interrelated variables, which are difficult to interpret [28]. Kaiser-Meyer-Olkin (KMO) and Bartlett tests were applied prior to the PCA. In this study, the sufficiency of KMO is 0.891 . The Bartlett test
$(\mathrm{P}=0.00)$ indicates that the variables are irrelevant. The KMO value should be $>0.5$; otherwise, the dataset will not be suitable for PCA [34].

Analytical data have been standardized with z-scale to avoid misclassification owing to large differences in data intensities $[33,35]$. In this study, eigenvalues $>1$ are significant and factors with eigenvalues $\geq 1$ are considered as possible inventory sources in the data, with the highest eigenvector sum being given the highest priority. Varimax normalization has been used to better interpret the results. All statistical analyses were performed with SPSS version 21.0 of Windows (IBM, New York, NY, USA).

\section{Results and Discussion}

The averages, standard deviations and minimummaximum values of the water-quality parameters according to seasonal variations are listed in Table 1. The water-quality classifications based on the minimum and maximum values of the water-quality parameters were performed according to the WHO and SWQR (Table 1) [21, 22].

According to the analysis results, annual mean values and standard deviation of water-quality parameters were determined to be $\mathrm{DO}=11.55 \pm 1.40 \mathrm{mg} \mathrm{L}^{-1}$, salinity $=0.36 \pm 0.21 \%$, $\mathrm{pH}=7.95 \pm 0.16$, WT $=$ $11.10 \pm 6.17^{\circ} \mathrm{C}, \quad \mathrm{EC}=249.22 \pm 30.88 \mu \mathrm{S} \mathrm{cm} \mathrm{cm}^{-1}, \quad \mathrm{SS}=$ $1.66 \pm 1.19 \mathrm{mg} \mathrm{L}^{-1}, \mathrm{COD}=0.69 \pm 0.67 \mathrm{mg} \mathrm{L}^{-1}, \mathrm{BOD}_{5}=$ $0.39 \pm 0.37 \mathrm{mg} \mathrm{L}^{-1},\left[\mathrm{Cl}^{-}\right]=7.52 \pm 1.33 \mathrm{mg} \mathrm{L}{ }^{-1},\left[\mathrm{PO}_{4}^{3-}\right]=$ $0.02 \pm 0.02 \mathrm{mg} \mathrm{L}^{-1},\left[\mathrm{Na}^{+}\right]=37.49 \pm 10.03 \mathrm{mg} \mathrm{L}^{-1},\left[\mathrm{~K}^{+}\right]=$ $5.02 \pm 1.23 \mathrm{mg} \mathrm{L}^{-1},\left[\mathrm{SO}_{4}{ }^{2-}\right]=31.76 \pm 25.52 \mathrm{mg} \mathrm{L}^{-1},\left[\mathrm{SO}_{3}{ }^{2-}\right]=$ $1.61 \pm 1.07 \mathrm{mg} \mathrm{L}^{-1},\left[\mathrm{Ca}^{2+}\right]=10.37 \pm 0.63 \mathrm{mg} \mathrm{L}^{-1},\left[\mathrm{Mg}^{2+}\right]=$ $9.59 \pm 0.37 \mathrm{mg} \mathrm{L}^{-1}, \mathrm{TH}=153.24 \pm 14.46 \mathrm{CaCO}_{3} \mathrm{mg} \mathrm{L}^{-1}$, $\mathrm{TA}=158.46 \pm 14.38 \quad \mathrm{CaCO}_{3} \mathrm{mg} \quad \mathrm{L}^{-1}, \quad\left[\mathrm{NO}_{2}^{-}\right]=$ $0.0007 \pm 0.0005 \mathrm{mg} \mathrm{L}^{-1},\left[\mathrm{NO}_{3}^{-}\right]=1.2758 \pm 0.9987 \mathrm{mg} \mathrm{L}^{-1}$, $\left[\mathrm{NH}_{4}^{+}\right]=0.0008 \pm 0.0006 \mathrm{mg} \mathrm{L}^{-1},\left[\mathrm{Fe}^{2+}\right]=0.0070 \pm 0.0040$ $\mathrm{mg} \mathrm{L} \mathrm{L}^{-1},\left[\mathrm{~Pb}^{2+}\right]=1.1400 \pm 0.5614 \mu \mathrm{g} \mathrm{L} \mathrm{L}^{-1},\left[\mathrm{Hg}^{2+}\right]=$ $0.0047 \pm 0.0038 \mu \mathrm{g} \mathrm{L}^{-1},\left[\mathrm{Ni}^{2+}\right]=6.4083 \pm 2.5520 \mu \mathrm{g} \mathrm{L}^{-1}$, $\left[\mathrm{Cu}^{2+}\right]=16.5333 \pm 7.5258 \mu \mathrm{g} \mathrm{L}^{-1},\left[\mathrm{Cd}^{2+}\right]=0.4958 \pm 0.3952$ $\mu \mathrm{g} \mathrm{L}{ }^{-1}$ and $\left[\mathrm{Zn}^{2+}\right]=10.7250 \pm 4.8350 \mu \mathrm{g} \mathrm{L}^{-1}$.

In this study, statistically significant differences ( $P>0.05$ ) have been found according to the results of one-way ANOVA of the mean values of the seasons and these differences are indicated using different letters in Table 1.

DO level vary between the values of 8.04 and $13.64 \mathrm{mg} \mathrm{L}^{-1}$. The DO at $\mathrm{P}<0.01$ and $\mathrm{P}<0.05$ significance level has high negative significance $(\mathrm{r} \geq-0.7)$ relation with salinity, WT, EC, SS, COD, BOD ${ }_{5},\left[\mathrm{SO}_{4}{ }^{2-}\right],\left[\mathrm{SO}_{3}{ }^{2-}\right]$, $\left[\mathrm{NO}_{2}^{-}\right],\left[\mathrm{NO}_{3}^{-}\right],\left[\mathrm{NH}_{4}^{+}\right]$(Table 2) and only positive significance relation is identified with $\left[\mathrm{Cl}^{-}\right]$. There is no danger for aquatic life in any season. This stream has been classified as Class I $\left(>8 \mathrm{mg} \mathrm{L}^{-1}\right)$ according to SWQR. According to the definition of Class I from the regulation, the term 'high-quality water' refers to surface water that may have high potential to be drinking water and can be used for recreational 
Table 1. Seasonal mean values, standard deviations and ranges (min.-max.) of water-quality parameters.

\begin{tabular}{|c|c|c|c|c|c|c|}
\hline & Winter & Spring & Summer & Autumn & $\begin{array}{l}\text { WHO } \\
\text { limits }\end{array}$ & $\begin{array}{l}\text { SWQR } \\
\text { (Class) }\end{array}$ \\
\hline DO $\left(\mathrm{mg} \mathrm{L}^{-1}\right)$ & $\begin{array}{l}12.96 \pm 0.69^{\mathrm{a}} \\
11.42-13.64\end{array}$ & $\begin{array}{l}12.12 \pm 0.51^{\mathrm{b}} \\
11.22-13.02\end{array}$ & $\begin{array}{c}10.79 \pm 1.05^{\mathrm{c}} \\
8.86-12.46\end{array}$ & $\begin{array}{c}10.34 \pm 1.30^{c} \\
8.04-12.54\end{array}$ & & I \\
\hline Salinity(\%o) & $\begin{array}{c}0.20 \pm 0.10^{\mathrm{a}} \\
0.10-.40\end{array}$ & $\begin{array}{c}0.27 \pm 0.11^{\mathrm{a}} \\
0.10-0.50\end{array}$ & $\begin{array}{c}0.48 \pm 0.18^{\mathrm{b}} \\
0.10-0.90\end{array}$ & $\begin{array}{c}0.49 \pm 0.22^{\mathrm{b}} \\
0.10-0.90\end{array}$ & & \\
\hline pH & $\begin{array}{c}7.83 \pm 0.06^{\mathrm{a}} \\
7.73-7.98\end{array}$ & $\begin{array}{c}7.85 \pm 0.14^{\mathrm{a}} \\
7.61-8.12\end{array}$ & $\begin{array}{c}8.05 \pm 0.09^{b} \\
7.88-8.24\end{array}$ & $\begin{array}{c}8.09 \pm 0.13^{b} \\
7.86-8.35\end{array}$ & $6.5-8.5$ & I \\
\hline WT $\left(C^{\circ}\right)$ & $\begin{array}{c}4.60 \pm 0.70^{\mathrm{a}} \\
4.00-7.30\end{array}$ & $\begin{array}{l}8.86 \pm 2.02^{\mathrm{b}} \\
5.90-12.80\end{array}$ & $\begin{array}{c}16.63 \pm 4.09^{c} \\
8.30-23.90\end{array}$ & $\begin{array}{c}14.30 \pm 6.61^{\mathrm{c}} \\
5.60-22.70\end{array}$ & & I \\
\hline $\mathrm{EC}\left(\mu \mathrm{S} \mathrm{cm}{ }^{-1}\right)$ & $\begin{array}{l}222.75 \pm 12.79^{a} \\
199.16-252.02\end{array}$ & $\begin{array}{l}236.30 \pm 18.37^{\mathrm{a}} \\
200.94-278.34\end{array}$ & $\begin{array}{l}270.22 \pm 27.68^{b} \\
213.74-318.48\end{array}$ & $\begin{array}{l}267.60 \pm 30.71^{b} \\
206.96-324.32\end{array}$ & 1500.0 & I \\
\hline $\mathrm{SS}\left(\mathrm{mg} \mathrm{L}^{-1}\right)$ & $\begin{array}{c}0.67 \pm 0.35^{\mathrm{a}} \\
0.0-1.32\end{array}$ & $\begin{array}{c}1.39 \pm 0.77^{\mathrm{ab}} \\
0.0-2.56\end{array}$ & $\begin{array}{c}2.30 \pm 1.08^{c} \\
0.02-3.74\end{array}$ & $\begin{array}{c}2.30 \pm 1.42^{\mathrm{bc}} \\
0.00-4.36\end{array}$ & & \\
\hline $\operatorname{COD}\left(\mathrm{mg} \mathrm{L}^{-1}\right)$ & $\begin{array}{c}0.05 \pm 0.13^{\mathrm{a}} \\
0.0-0.60\end{array}$ & $\begin{array}{c}0.50 \pm 0.30^{\mathrm{b}} \\
0.0-1.04\end{array}$ & $\begin{array}{c}0.89 \pm 0.63^{\mathrm{c}} \\
0.00-2.34\end{array}$ & $\begin{array}{l}1.30 \pm 0.67^{\mathrm{d}} \\
0.00-2.22\end{array}$ & 10.0 & I \\
\hline BOD $_{5}\left(\mathrm{mg} \mathrm{L}^{-1}\right)$ & $\begin{array}{c}0.07 \pm 0.10^{\mathrm{a}} \\
0.00-0.32\end{array}$ & $\begin{array}{c}0.30 \pm 0.20^{\mathrm{b}} \\
0.00-0.80\end{array}$ & $\begin{array}{c}0.56 \pm 0.37^{c} \\
0.00-1.14\end{array}$ & $\begin{array}{c}0.62 \pm 0.41^{\mathrm{c}} \\
0.00-1.20\end{array}$ & & I \\
\hline $\mathrm{Cl}^{-}\left(\mathrm{mg} \mathrm{L}^{-1}\right)$ & $\begin{array}{c}8.38 \pm 0.23^{\mathrm{a}} \\
8.08-9.20\end{array}$ & $\begin{array}{l}8.07 \pm 0.51^{\mathrm{a}} \\
7.22-8.54\end{array}$ & $\begin{array}{l}6.95 \pm 2.12^{\mathrm{b}} \\
3.84-10.28\end{array}$ & $\begin{array}{c}6.68 \pm 0.61^{\mathrm{b}} \\
5.76-8.00\end{array}$ & 250.0 & III \\
\hline $\mathrm{PO}_{4}^{3-}\left(\mathrm{mg} \mathrm{L}^{-1}\right)$ & $\begin{array}{c}0.01 \pm 0.01^{\mathrm{a}} \\
0.0-0.02\end{array}$ & $\begin{array}{c}0.01 \pm 0.01^{\mathrm{a}} \\
0.0 \pm 0.02\end{array}$ & $\begin{array}{c}0.02 \pm 0.02^{\mathrm{b}} \\
0.0-0.08\end{array}$ & $\begin{array}{c}0.03 \pm 0.02^{\mathrm{b}} \\
0.0-0.06\end{array}$ & & II \\
\hline $\mathrm{SO}_{4}^{2-}\left(\mathrm{mg} \mathrm{L}^{-1}\right)$ & $\begin{array}{l}6.99 \pm 4.16^{\mathrm{a}} \\
0.30-13.78\end{array}$ & $\begin{array}{c}29.41 \pm 21.31^{b} \\
0.74-58.42\end{array}$ & $\begin{array}{c}49.33 \pm 21.21^{\mathrm{bc}} \\
1.30-67.93\end{array}$ & $\begin{array}{c}41.34 \pm 26.38^{c} \\
0.61-75.51\end{array}$ & 250.0 & \\
\hline $\mathrm{SO}_{3}^{2-}\left(\mathrm{mg} \mathrm{L}^{-1}\right)$ & $\begin{array}{c}0.63 \pm 0.49^{\mathrm{a}} \\
0.02-1.64\end{array}$ & $\begin{array}{c}1.27 \pm 0.76 b \\
0.05-2.68\end{array}$ & $\begin{array}{c}2.23 \pm 0.86^{c} \\
0.35-3.58\end{array}$ & $\begin{array}{c}2.32 \pm 1.07^{c} \\
0.25-4.10\end{array}$ & & III \\
\hline $\mathrm{Na}^{+}\left(\mathrm{mg} \mathrm{L}^{-1}\right)$ & $\begin{array}{l}34.68 \pm 6.64^{\mathrm{ab}} \\
22.44-47.80\end{array}$ & $\begin{array}{c}42.42 \pm 10.03^{c} \\
21.64-58.94\end{array}$ & $\begin{array}{c}40.26 \pm 13.10^{\mathrm{bc}} \\
22.37-68.54\end{array}$ & $\begin{array}{l}32.59 \pm 5.53^{\mathrm{a}} \\
22.34-42.92\end{array}$ & 200.0 & \\
\hline $\mathbf{K}^{+}\left(\mathbf{m g ~ \mathbf { L } ^ { - 1 }}\right)$ & $\begin{array}{l}4.33 \pm 1.41^{\mathrm{a}} \\
1.44-6.62\end{array}$ & $\begin{array}{c}5.55 \pm 1.12^{\mathrm{b}} \\
3.72-7.28\end{array}$ & $\begin{array}{c}5.40 \pm 1.08^{\mathrm{b}} \\
3.80-7.30\end{array}$ & $\begin{array}{c}4.81 \pm 0.90^{\mathrm{ab}} \\
3.59-6.66\end{array}$ & 12.0 & \\
\hline $\mathrm{TH}\left(\mathrm{CaCO}_{3} \mathrm{mg} \mathrm{L}^{-1}\right)$ & $\begin{array}{c}139.53 \pm 4.51^{\mathrm{a}} \\
133.32-148.92\end{array}$ & $\begin{array}{l}157.17 \pm 13.73^{b} \\
138.12-178.98\end{array}$ & $\begin{array}{l}160.26 \pm 17.39^{b} \\
137.22-190.24\end{array}$ & $\begin{array}{c}155.98 \pm 8.82^{\mathrm{b}} \\
137.04-171.34\end{array}$ & & \\
\hline TA $\left(\mathrm{CaCO}_{3} \mathrm{mg} \mathrm{L}^{-1}\right)$ & $\begin{array}{c}145.02 \pm 4.29^{\mathrm{a}} \\
139.13-153.48\end{array}$ & $\begin{array}{l}162.62 \pm 14.25^{\mathrm{bc}} \\
144.26-185.06\end{array}$ & $\begin{array}{l}167.23 \pm 16.27^{c} \\
143.18-195.98\end{array}$ & $\begin{array}{c}158.96 \pm 8.82^{\mathrm{b}} \\
143.06-173.48\end{array}$ & 200 & \\
\hline $\mathrm{Mg}^{2+}\left(\mathrm{mg} \mathrm{L}^{-1}\right)$ & $\begin{array}{c}9.41 \pm 0.19^{\mathrm{a}} \\
9.04-9.76\end{array}$ & $\begin{array}{l}9.67 \pm 0.38^{b} \\
9.12-10.44\end{array}$ & $\begin{array}{l}9.74 \pm 0.52^{\mathrm{b}} \\
9.08-10.80\end{array}$ & $\begin{array}{c}9.53 \pm 0.22^{\mathrm{ab}} \\
9.12-10.04\end{array}$ & 50 & \\
\hline $\mathrm{Ca}^{2+}\left(\mathrm{mg} \mathrm{L}^{-1}\right)$ & $\begin{array}{l}10.02 \pm 0.34^{\mathrm{a}} \\
9.49-10.65\end{array}$ & $\begin{array}{c}10.68 \pm 0.79^{c} \\
9.62-12.10\end{array}$ & $\begin{array}{c}10.57 \pm 0.67^{\mathrm{bc}} \\
9.65-11.95\end{array}$ & $\begin{array}{c}10.23 \pm 0.42^{\mathrm{ab}} \\
9.36-10.95\end{array}$ & 300 & \\
\hline $\mathrm{NO}_{2}^{-}\left(\mathrm{mg} \mathrm{L}^{-1}\right)$ & $\begin{array}{c}0.0003 \pm 0.0002^{\mathrm{a}} \\
0.0-0.0009\end{array}$ & $\begin{array}{l}0.0006 \pm 0.0003^{b} \\
0.0001-0.0012\end{array}$ & $\begin{array}{l}0.0012 \pm 0.0005^{\mathrm{c}} \\
0.0001-0.0021\end{array}$ & $\begin{array}{c}0.0009 \pm 0.0005^{\mathrm{b}} \\
0.0001-0.0016\end{array}$ & & I \\
\hline $\mathrm{NO}_{3}^{-}\left(\mathrm{mg} \mathrm{L}^{-1}\right)$ & $\begin{array}{c}0.437 \pm 0.337^{\mathrm{a}} \\
0.0-1.20\end{array}$ & $\begin{array}{c}0.740 \pm 0.464^{\mathrm{a}} \\
0.10-1.70\end{array}$ & $\begin{array}{c}1.960 \pm 0.813^{b} \\
0.30-3.30\end{array}$ & $\begin{array}{c}1.967 \pm 1.049^{\mathrm{b}} \\
0.10-3.90\end{array}$ & 50 & I \\
\hline $\mathrm{NH}_{4}^{+}\left(\mathrm{mg} \mathrm{L}^{-1}\right)$ & $\begin{array}{c}0.0004 \pm 0.0003^{\mathrm{a}} \\
0.0-0.0011\end{array}$ & $\begin{array}{c}0.0007 \pm 0.0004^{b} \\
0.0001-0.0017\end{array}$ & $\begin{array}{c}0.0014 \pm 0.0006^{c} \\
0.0002-0.0024\end{array}$ & $\begin{array}{c}0.0009 \pm 0.0005^{\mathrm{b}} \\
0.0001-0.0018\end{array}$ & 35 & I \\
\hline $\mathrm{Fe}^{2+}\left(\mathrm{mg} \mathrm{L}^{-1}\right)$ & $\begin{array}{c}0.0061 \pm 0.0024^{\mathrm{a}} \\
0.0020-0.0120\end{array}$ & $\begin{array}{c}0.0100 \pm 0.005^{\mathrm{b}} \\
0.0020-0.0210\end{array}$ & $\begin{array}{c}0.0056 \pm 0.0026^{\mathrm{a}} \\
0.0010-0.0120\end{array}$ & $\begin{array}{c}0.0064 \pm 0.0031^{\mathrm{a}} \\
0.0020-0.0140\end{array}$ & 0.300 & I \\
\hline $\mathbf{P b}^{2+}\left(\mu \mathrm{g} \mathrm{L}^{-1}\right)$ & $\begin{array}{c}0.987 \pm 0.447^{\mathrm{a}} \\
0.20-1.90\end{array}$ & $\begin{array}{c}1.473 \pm 0.709^{\mathrm{b}} \\
0.20-2.80\end{array}$ & $\begin{array}{c}1.117 \pm 0.473^{\mathrm{ab}} \\
0.20-2.10\end{array}$ & $\begin{array}{c}0.983 \pm 0.450^{\mathrm{a}} \\
0.20-2.10\end{array}$ & 10 & I \\
\hline $\mathrm{Cu}^{2+}\left(\mu \mathrm{g} \mathrm{L}^{-1}\right)$ & $\begin{array}{c}15.633 \pm 5.666^{\mathrm{a}} \\
3.0000-26.00\end{array}$ & $\begin{array}{c}21.10 \pm 8.953^{\mathrm{b}} \\
3.00-38.00\end{array}$ & $\begin{array}{c}14.167 \pm 5.902^{\mathrm{a}} \\
3.00-26.00\end{array}$ & $\begin{array}{c}15.233 \pm 7.440^{\mathrm{a}} \\
3.00-32.00\end{array}$ & 20 & I \\
\hline $\mathrm{Cd}^{2+}\left(\mu \mathrm{g} \mathrm{L}^{-1}\right)$ & $\begin{array}{c}0.357 \pm 0.211^{\mathrm{a}} \\
0.0-0.70\end{array}$ & $\begin{array}{c}0.410 \pm 0.272^{\mathrm{a}} \\
0.0-1.00\end{array}$ & $\begin{array}{c}0.313 \pm 0.236^{\mathrm{a}} \\
0.0-0.800\end{array}$ & $\begin{array}{c}0.903 \pm 0.482^{\mathrm{b}} \\
0.0-1.70\end{array}$ & & I \\
\hline $\mathrm{Hg}^{2+}\left(\mu \mathrm{g} \mathrm{L}^{-1}\right)$ & $\begin{array}{c}0.0029 \pm 0.0016^{\mathrm{a}} \\
0.0-0.0060\end{array}$ & $\begin{array}{c}0.0057 \pm 0.0031^{\mathrm{bc}} \\
0.0-0.0120\end{array}$ & $\begin{array}{c}0.0039 \pm 0.0026^{\mathrm{ab}} \\
0.0-0.0090\end{array}$ & $\begin{array}{c}0.0064 \pm 0.0056^{c} \\
0.0-0.0190\end{array}$ & & I \\
\hline
\end{tabular}


Table 1. Continued.

\begin{tabular}{|c|c|c|c|c|c|c|}
\hline $\mathrm{Ni}^{2+}\left(\mu \mathrm{g} \mathrm{L}^{-1}\right)$ & $\begin{array}{c}5.667 \pm 2.155^{\mathrm{a}} \\
3.00-11.00\end{array}$ & $\begin{array}{c}7.80 \pm 2.833^{\mathrm{b}} \\
3.00-13.00\end{array}$ & $\begin{array}{c}5.900 \pm 2.468^{\mathrm{a}} \\
3.00-12.0\end{array}$ & $\begin{array}{c}6.267 \pm 2.258^{\mathrm{ab}} \\
3.00-11.00\end{array}$ & & I \\
\hline $\mathbf{Z n}^{2+}\left(\mu \mathrm{g} \mathrm{L}^{-1}\right)$ & $\begin{array}{c}8.133 \pm 2.801^{\mathrm{a}} \\
4.00-14.00\end{array}$ & $\begin{array}{c}15.000 \pm 5.534^{\mathrm{b}} \\
4.00-26.00\end{array}$ & $\begin{array}{c}10.367 \pm 4.148^{\mathrm{a}} \\
0.0-18.00\end{array}$ & $\begin{array}{c}9.40 \pm 3.529^{\mathrm{a}} \\
4.00-18.00\end{array}$ & 10 & I \\
\hline
\end{tabular}

purposes including those requiring body contact such as swimming and water suitable for trout or animal production or farming needs $[21,22]$.

The salinity was found between 0.10 and 0.90 (\%). Salinity changes do not pose a risk for the aquatic life in the stream. This parameter shows high positive significance with $\mathrm{pH}, \mathrm{WT}, \mathrm{EC}, \mathrm{SS}, \mathrm{COD}, \mathrm{BOD}_{5},\left[\mathrm{SO}_{4}{ }^{2-}\right]$ $\left[\mathrm{SO}_{3}{ }^{2-}\right],\left[\mathrm{NO}^{2-}\right],\left[\mathrm{NO}_{3}^{-}\right],\left[\mathrm{NH}_{4}^{+}\right](\mathrm{r} \geq-0.7)$, and it has negative significance relation only with $\left[\mathrm{Cl}^{-}\right]$(Table 2 ).

The $\mathrm{pH}$ varies between 7.61 and 8.35. The parameter at $\mathrm{P}<0.01$ and $\mathrm{P}<0.05$ significance level with high positive significance $(\mathrm{r} \geq 0.7)$ are salinity, WT, EC, SS, $\mathrm{COD}, \mathrm{BOD}_{5},\left[\mathrm{SO}_{4}{ }^{2-}\right],\left[\mathrm{SO}_{3}{ }^{2-}\right],\left[\mathrm{NO}_{2}^{-}\right],\left[\mathrm{NO}_{3}^{-}\right],\left[\mathrm{NH}_{4}^{+}\right]$ and with negative relation with $\mathrm{DO}$ and $\left[\mathrm{Cl}^{-}\right]$(Table 2). The $\mathrm{pH}$ of this stream is Class I (6.5-8.5) (WHO 2011; SWQR 2016) $[21,22]$. The WT varies between $4.00^{\circ} \mathrm{C}$ and $23.90^{\circ} \mathrm{C}$. This parameter at $\mathrm{P}<0.01$ and $\mathrm{P}<0.05$ significance level has demonstrated high positive significance $(\mathrm{r} \geq 0.7)$ relation with salinity, $\mathrm{pH}, \mathrm{EC}, \mathrm{SS}$, $\mathrm{COD}, \mathrm{BOD}_{5},\left[\mathrm{SO}_{4}{ }^{2-}\right],\left[\mathrm{SO}_{3}{ }^{2-}\right],\left[\mathrm{NO}_{2}^{-}\right],\left[\mathrm{NO}_{3}^{-}\right],\left[\mathrm{NH}_{4}^{+}\right]$, and negative significance relation with $\mathrm{DO},\left[\mathrm{Cl}^{-}\right],\left[\mathrm{Fe}^{2+}\right]$ and $\left[\mathrm{Cu}^{2+}\right]$ (Table 2). Since there is no seasonal threat in terms of WT to Karaboğaz Stream, it is also suitable for aquatic life. Moreover, according to SWQR's inland water-quality criteria, the highest temperature of the Stream is Class I $(\leq 25)$ (Table 1) [21, 22].

The EC value variates between 199.16 and $324.32 \mu \mathrm{S} \mathrm{cm}^{-1}$. EC at $\mathrm{P}<0.01$ and $\mathrm{P}<0.05$ significance level, parameters with high positive significance $(\mathrm{r} \geq 0.7$ ) are salinity, $\mathrm{pH}, \mathrm{WT}, \mathrm{SS}, \mathrm{COD}, \mathrm{BOD}_{5},\left[\mathrm{SO}_{4}{ }^{2-}\right],\left[\mathrm{SO}_{3}{ }^{2-}\right]$, $\left[\mathrm{NO}_{2}^{-}\right],\left[\mathrm{NO}_{3}^{-}\right]$and $\left[\mathrm{NH}_{4}^{+}\right]$. These parameters indicate a negative significance relation with $\mathrm{DO}$ and $\left[\mathrm{Cl}^{-}\right]$ (Table 3). According to the classification criteria of the SWQR and WHO guidelines, the Karaboğaz Stream is class I in terms of EC $\left(<400 \mu \mathrm{S} \mathrm{cm}^{-1}\right)$ (Table 1) [21, 22].

The SS level of Karaboğaz Stream is between 0.00 and $4.36 \mathrm{mg} \mathrm{\textrm {L } ^ { - 1 }}$. The parameter has high positive relation $(\mathrm{r} \geq 0.7)$ with $\mathrm{pH}, \mathrm{WT}, \mathrm{EC}, \mathrm{COD}, \mathrm{BOD}_{5},\left[\mathrm{SO}_{4}{ }^{2-}\right]$, $\left[\mathrm{SO}_{3}{ }^{2-}\right],\left[\mathrm{NO}_{2}^{-}\right],\left[\mathrm{NO}_{3}^{-}\right],\left[\mathrm{NH}_{4}^{+}\right]$. The $\mathrm{SS}$ indicates a negative relation with DO and $\left[\mathrm{Cl}^{-}\right]$(Table 2). The COD value variates between 0.00 and $2.34 \mathrm{mg} \mathrm{L}^{-1}$. This parameter at $\mathrm{P}<0.01$ and $\mathrm{P}<0.05$ significance level was found to be high positive $(\mathrm{r} \geq 0.7)$ on salinity, $\mathrm{pH}, \mathrm{WT}$, $\mathrm{EC}, \mathrm{SS}, \mathrm{BOD}_{5},\left[\mathrm{SO}_{4}{ }^{2-}\right],\left[\mathrm{SO}_{3}{ }^{2-}\right],\left[\mathrm{NO}_{3}^{-}\right]$, and negative significant relation with DO and $\left[\mathrm{Cl}^{-}\right]$(Table 2). According to the WHO and SWQR's criteria, the COD value of this stream is Class I $(\leq 25)$ (Table 1$)$ [21, 22].

The value of biological oxygen demand varies between 0.00 and $1.20 \mathrm{mg} \mathrm{L} \mathrm{L}^{-1}$. It has high positive $(\mathrm{r} \geq 0.7)$ relation with $\mathrm{BOD}_{5}$, at the significance level of $\mathrm{P}<0.01$ and $\mathrm{P}<0.05, \mathrm{pH}, \mathrm{WT}, \mathrm{EC}, \mathrm{SS}, \mathrm{COD},\left[\mathrm{SO}_{4}{ }^{2-}\right]$,
$\left[\mathrm{SO}_{3}{ }^{2-}\right],\left[\mathrm{NO}_{2}^{-}\right],\left[\mathrm{NO}_{3}^{-}\right],\left[\mathrm{NH}_{4}^{+}\right]$, and negative significant relation with DO and $\left[\mathrm{Cl}^{-}\right]$(Table 2). According to water-quality classification regulations, the Karaboğaz Stream's BOD 5 values are in Class I [21, 22].

The chloride value varies between 3.84 and $10.28 \mathrm{mg} \mathrm{L}^{-1}$. This parameter at $\mathrm{P}<0.01$ and $\mathrm{P}<0.05$ significance level has positive significance with DO, $\left[\mathrm{Na}^{+}\right],\left[\mathrm{Mg}^{2+}\right]$, and has negative significance relation with salinity, $\mathrm{pH}, \mathrm{WT}, \mathrm{EC}, \mathrm{SS}, \mathrm{COD}, \mathrm{BOD}_{5},\left[\mathrm{PO}_{4}^{3-}\right]$, $\left[\mathrm{SO}_{4}^{2-}\right],\left[\mathrm{SO}_{3}{ }^{2-}\right],\left[\mathrm{NO}_{2}^{-}\right],\left[\mathrm{NO}_{3}^{-}\right],\left[\mathrm{NH}_{4}^{+}\right],\left[\mathrm{Cd}^{2+}\right],\left[\mathrm{Ni}^{2+}\right]$ (Table 3). The chlorine value is Class III $\left(<50 \mathrm{mg} \mathrm{L}^{-1}\right)$ according to the water-quality criteria. In the regulation, 'Polluted water' is defined as the water, which can be used for the production of aquaculture after a suitable treatment, or industry water except for facilities such as food or textiles requiring high-quality water [21, 22].

The phosphorus level is between 0.00 and $0.080 \mathrm{mg} \mathrm{L} \mathrm{L}^{-1}$. The parameter at $\mathrm{P}<0.01$ and $\mathrm{P}<0.05$ significance level, has positive $(r \geq 0.5)$ significance with salinity, $\mathrm{pH}, \mathrm{WT}, \mathrm{EC}, \mathrm{SS}, \mathrm{COD},\left[\mathrm{SO}_{4}{ }^{2-}\right],\left[\mathrm{SO}_{3}{ }^{2-}\right],\left[\mathrm{NO}_{2}{ }^{-}\right]$, $\left[\mathrm{NO}_{3}^{-}\right]$and $\left[\mathrm{NH}_{4}^{+}\right]$and negative significance with DO and $\left[\mathrm{Cl}^{-}\right]$(Table 2). According to SWQR, the phosphate is Class II $(<0.16)$ [21, 22]. In the regulation, this class is defined as 'less polluted water', which refers to surface waters with potential to become drinking water, the water that can be used for recreational purposes, the water that can be used for the production of fishes other than trout and the irrigation water if the quality criteria determined by in placed regulations is met. The amount of phosphorus in this stream is considerably less than that of Yağlıdere Stream [15].

The sulphate concentration of the stream varies between 0.30 and $75.51 \mathrm{mg} \mathrm{L^{-1 }}$. The acceptable limit of sulphate ion for aquatic organisms is $90 \mathrm{mg} \mathrm{L}^{-1}$ [31]. This parameter at $\mathrm{P}<0.01$ and $\mathrm{P}<0.05$ significance level has positive $(\mathrm{r} \geq 0.7)$ relation with salinity, $\mathrm{pH}, \mathrm{WT}, \mathrm{EC}$, $\mathrm{SS}, \mathrm{COD}, \mathrm{BOD}_{5},\left[\mathrm{SO}_{3}{ }^{2-}\right],\left[\mathrm{NO}_{2}^{-}\right],\left[\mathrm{NO}_{3}^{-}\right]$and $\left[\mathrm{NH}_{4}^{+}\right]$ and negative significance relation with DO and $\left[\mathrm{Cl}^{-}\right]$ (Table 2).

The sulphide concentration varies between 0.02 and $4.10 \mathrm{mg} \mathrm{L}^{-1}$. This parameter at $\mathrm{P}<0.01$ and $\mathrm{P}<0.05$ significance level has positive $(r \geq 0.7)$ relation with salinity, pH, WT, EC, SS, COD, $\mathrm{BOD}_{5},\left[\mathrm{SO}_{4}{ }^{2-}\right],\left[\mathrm{NO}_{2}{ }^{-}\right]$, $\left[\mathrm{NO}_{3}^{-}\right],\left[\mathrm{NH}_{4}^{+}\right]$, and negative significance relation with DO and $\left[\mathrm{Cl}^{-}\right]$(Table 2). In terms of sulphide is Class III $\left(<10 \mathrm{mg} \mathrm{L}^{-1}\right)[21,22]$. The amount of sulphide in the Kuruçay stream has been identified higher than that of Karaboğaz Stream [35].

The sodium concentration varies between 21.64 and $68.54 \mathrm{mg} \mathrm{L}^{-1}$. This parameter at $\mathrm{P}<0.01$ and $\mathrm{P}<0.05$ significance level has high positive $(r \geq 0.7)$ significance 


\begin{tabular}{|c|c|c|c|c|c|c|c|c|c|c|c|c|c|c|c|c|c|c|c|c|c|c|c|c|c|c|c|c|c|}
\hline Nี & & & & & & & & & & & & & & & & & & & & & & & & & & & & & \\
\hline 㞷 & & & & & & & & & & & & & & & & & & & & & & & & & & & & 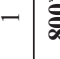 & \\
\hline 等 & & & & & & & & & & & & & & & & & & & & & & & & & & & & $\widehat{a}$ & \\
\hline 筞 & & & & & & & & & & & & & & & & & & & & & & & & & & & 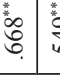 & 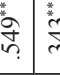 & \\
\hline$\tilde{J}^{7}$ & & & & & & & & & & & & & & & & & & & & & & & & & & & 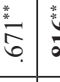 & $\begin{array}{ll}0 \\
\infty \\
\infty\end{array}$ & \\
\hline 焉 & & & & & & & & & & & & & & & & & & & & & & & & & 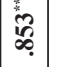 & 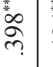 & 守 & ك. & \\
\hline 袄 & & & & & & & & & & & & & & & & & & & & & & & - & ○. & 苟 & 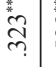 & 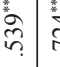 & $\stackrel{t}{C}$ & \\
\hline$\overline{\mathrm{z}}^{+}$ & & & & & & & & & & & & & & & & & & & & & & & $\mid \begin{array}{l}* \\
0 \\
m \\
m\end{array}$ & 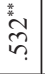 & $\mid \begin{array}{c}0 \\
\infty \\
0 \\
m \\
?\end{array}$ & $\stackrel{m}{m}$ & 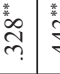 & 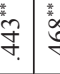 & \\
\hline z) & & & & & & & & & & & & & & & & & & & & & - & 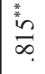 & $\stackrel{m}{\oplus}$ & 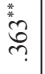 & $\stackrel{\oplus}{\hookrightarrow}$ & 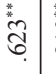 & 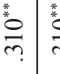 & $\frac{\dot{m}}{m}$ & \\
\hline$\overbrace{}^{\circ}$ & & & & & & & & & & & & & & & & & & & & - & \begin{tabular}{|l}
$\mathbf{0}$ \\
$\infty$ \\
$\infty$
\end{tabular} & బ. & $\mid$\begin{tabular}{c}
$*$ \\
\multirow{2}{*}{} \\
$m$ \\
$m$
\end{tabular} & 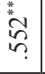 & 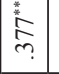 & 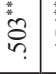 & 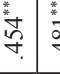 & $\stackrel{s}{s}$ & \\
\hline U. & & & & & & & & & & & & & & & & & & & - & $\bar{n}$ & $\begin{array}{l}0 \\
\stackrel{0}{m}\end{array}$ & 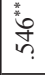 & 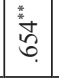 & 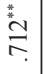 & $\left|\begin{array}{l}0 \\
0 \\
0 \\
0 \\
0\end{array}\right|$ & 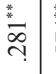 & $\begin{array}{c}* \\
\vdots \\
i n n\end{array}$ & 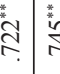 & \\
\hline${ }^{50}$ & & & & & & & & & & & & & & & & & & - & ڤึ & 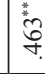 & 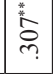 & 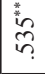 & $\begin{array}{l}\text { 養 } \\
\end{array}$ & 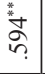 & 范 & ָั๋ & 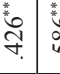 & 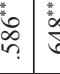 & \\
\hline 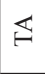 & & & & & & & & & & & & & & & & & - & 童 & ?ִ. & \% & $\begin{array}{l}* \\
\hat{q} \\
\hat{q}\end{array}$ & $\frac{0}{6}$ & 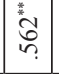 & 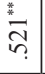 & 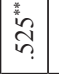 & $\vec{\infty}$ & $\begin{array}{l}* \\
\vdots \\
n \\
n\end{array}$ & 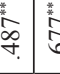 & \\
\hline 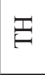 & & & & & & & & & & & & & & & & - & 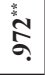 & $\frac{\overrightarrow{0}}{\partial}$ & 童 & 离 & 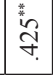 & 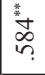 & 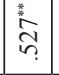 & 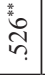 & $\overrightarrow{\bar{\sigma}}$ & 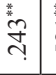 & $\vec{v}$ & $\begin{array}{l}\tilde{c} \\
n \\
n\end{array}$ & \\
\hline \pm & & & & & & & & & & & & & & & - & $\vec{z}$ & 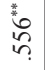 & 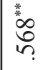 & م. & $\begin{array}{l}0 \\
6 \\
6 \\
6\end{array}$ & $\mid$\begin{tabular}{l}
\multirow{2}{y}{} \\
$\bar{y}$
\end{tabular} & 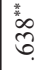 & 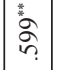 & 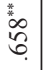 & 茪 & ఫั & $\begin{array}{l}n \\
0\end{array}$ & 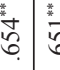 & 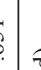 \\
\hline 范 & & & & & & & & & & & & & & - & 党 & $\frac{6}{2}$ & . & 㤐 & 弯 & ঙ্t & $\stackrel{\infty}{\leftrightharpoons}$ & 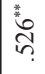 & 尌 & 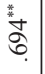 & 悉 & है & 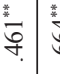 & مَ & 5 \\
\hline 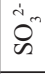 & & & & & & & & & & & & & - & . & 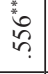 & 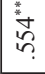 & 要 & 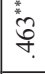 & 籴 & $\Xi$ & ta. & : & $\mid \begin{array}{c}n \\
\tilde{m} \\
m \\
m\end{array}$ & \begin{tabular}{l}
$\vdots$ \\
$\vdots$ \\
\hdashline \\
\hdashline
\end{tabular} & 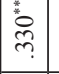 & 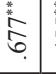 & 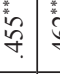 & 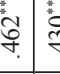 & $\frac{3}{3}$ \\
\hline $\begin{array}{l}\dot{1}^{+}+ \\
\dot{\infty}^{+}\end{array}$ & & & & & & & & & & & - & & $\stackrel{\Delta}{a}$ & ڤ్ & 它 & 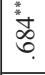 & 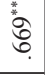 & 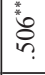 & 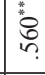 & ర్య & 总 & 竦 & लैं & 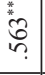 & $\stackrel{m}{m}$ & $\stackrel{*}{\bar{n}} \bar{n}$ & 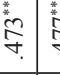 & $\begin{array}{l}c \\
f \\
f\end{array}$ & $?$ \\
\hline $0^{+}$ & & & & & & & & & & 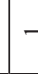 & 2 & & 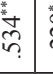 & ते & 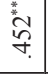 & 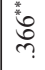 & 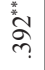 & 范 & 党 & $\frac{1}{6}$ & 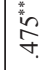 & 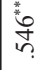 & $\begin{array}{l}0 \\
b \\
m \\
m\end{array}$ & $\vec{\sim}$ & $\frac{\vdots}{\bar{y}}$ & ֶָ. & 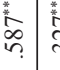 & है & ب़ \\
\hline$\dot{U}$ & & & & & & & & & - & $\frac{\pi}{7}$ & 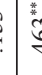 & & 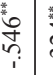 & 䓠 & $\stackrel{0}{0}$ & $\cong$ & gे & $\stackrel{\sim}{\check{\sigma}}$ & $\stackrel{\circ}{\hookrightarrow}$ & $\begin{array}{l}0 \\
y \\
1\end{array}$ & \begin{tabular}{|l}
0 \\
0 \\
0 \\
0 \\
0
\end{tabular} & ?. & 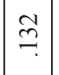 & $\overrightarrow{\underline{g}}$ & $\mid \begin{array}{c}* \\
\infty \\
\rightarrow\end{array}$ & ?. & 厄. & 2 & $\mid \begin{array}{l}0 \\
y \\
.0\end{array}$ \\
\hline రి & & & & & & & & - & م: & 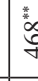 & $\%$ & & $\frac{\infty}{a}$ & $\cong$ & $\begin{array}{l}0 \\
\vdots \\
q \\
q\end{array}$ & 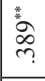 & 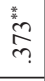 & 今ે & $\frac{n}{m}$ & $\begin{array}{l}* \\
k \\
\infty\end{array}$ & 势 & 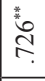 & $\mid$\begin{tabular}{l}
$\infty$ \\
$\infty$ \\
\hdashline
\end{tabular} & 装 & $\stackrel{\substack{\infty \\
\stackrel{\infty}{\rightarrow}}}{\rightarrow}$ & 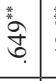 & 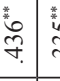 & 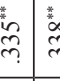 & ? \\
\hline 80 & & & & & & & - & $\tilde{\sigma}$ & $\tilde{\pi}$ & $\frac{d}{2}$ & $\tilde{z}$ & 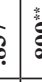 & م. & 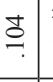 & 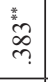 & 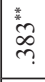 & ڤ్రి & $\vec{\vdots}$ & 華 & $\stackrel{*}{\stackrel{*}{f}}$ & to & 党 & $\mid$\begin{tabular}{l}
$\infty$ \\
\hdashline
\end{tabular} & $\vec{m}$ & \begin{tabular}{c}
$*$ \\
$\infty$ \\
\hdashline \\
\end{tabular} & : & 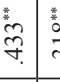 & $\begin{array}{l}\infty \\
m \\
m\end{array}$ & 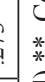 \\
\hline$\tilde{\approx}$ & & & & & & - & s. & ตุ. & 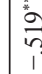 & g & 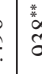 & 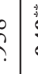 & 实 & 童 & 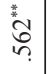 & 离 & 索 & 悉 & $\frac{z}{8}$ & S. & ซึ & 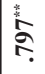 & 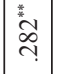 & 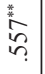 & ले & 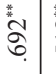 & 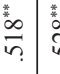 & ڤ్ & S. \\
\hline 品 & & & & & - & ₹̛̃ & $\bar{\infty}$ & 亏ั & 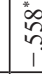 & 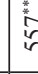 & 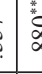 & 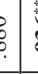 & 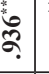 & กิ & 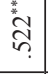 & | & $\begin{array}{l}0 \\
0 \\
0 \\
0 \\
4\end{array}$ & లై & 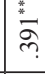 & ţ. & is & 卷 & 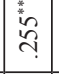 & 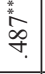 & 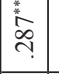 & 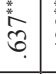 & 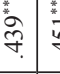 & s. & 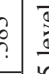 \\
\hline 5 & & & & - & 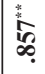 & ڤִ & : & $\infty_{\infty}^{\infty}$ & 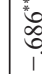 & 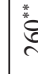 & $\check{E}$ & $\frac{f}{6}$ & 焉 & ฮิ. & ڤִ & ปิ & 皇 & . & તิ่ & . & ڤે & $\frac{7}{2}$ & $\mid \begin{array}{l}n \\
\tilde{o} \\
1\end{array}$ & $\stackrel{\infty}{\sim}$ & $\left|\begin{array}{l}n \\
0 \\
1\end{array}\right|$ & $\vec{\sigma}$ & 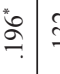 & 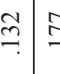 & 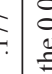 \\
\hline$\stackrel{T}{2}$ & & & - & $\frac{b}{\infty}$ & to & 㐫 & : & $\bar{\infty}$ & ֶె & $\bar{g}$ & 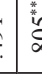 & & 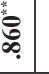 & $\stackrel{\infty}{=}$ & जे & 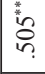 & 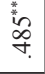 & 党 & $\frac{\tilde{y}}{m}$ & $\stackrel{\infty}{1}$ & $\begin{array}{l}\bar{z} \\
\bar{\alpha} \\
\infty \\
\infty\end{array}$ & 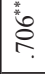 & $\stackrel{9}{?}$ & 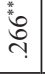 & $\mid \begin{array}{c}\infty \\
0 \\
0\end{array}$ & 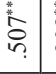 & 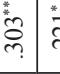 & $\overrightarrow{\mathrm{\sim}}$ & 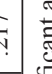 \\
\hline त्ञ & & - & $\frac{k}{\infty}$ & 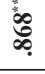 & $\frac{5}{2}$ & گ̆ & ฉి & $\stackrel{\leftrightarrow}{\circ}$ & 8 & F & 8 & 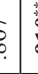 & $\frac{\pi}{2}$ & $\underline{\underline{\sigma}}$ & 商 & 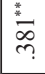 & 点 & 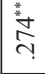 & 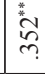 & ه. & $\stackrel{\pi^{*}}{\tilde{~}}$ & 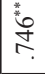 & $\mid \begin{array}{c}n \\
?\end{array}$ & 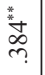 & $\stackrel{\infty}{\leftrightharpoons}$ & 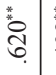 & 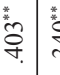 & 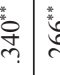 & بـ \\
\hline ̊ & - & 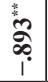 & {$\left[\begin{array}{c}\infty \\
\infty \\
\vdots \\
1\end{array}\right.$} & $\begin{array}{c}\infty \\
\infty \\
\infty \\
i \\
\end{array}$ & $\begin{array}{c}r \\
\infty \\
i \\
i \\
i\end{array}$ & 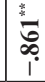 & $\begin{array}{l}0 \\
\infty \\
\infty \\
1\end{array}$ & $\div$ & $\stackrel{8}{8}$ & 4 & ? & & ל. & 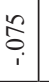 & 年 & \begin{tabular}{|l}
$\infty$ \\
$\infty$ \\
$p_{1}^{\infty}$ \\
1
\end{tabular} & $\begin{array}{l}0 \\
0 \\
0 \\
1 \\
1\end{array}$ & $\frac{2}{1}$ & 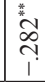 & 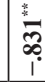 & $\frac{\infty}{\alpha}$ & 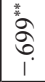 & $\mid$\begin{tabular}{|c}
$\infty$ \\
0 \\
0 \\
1
\end{tabular} & ְ. & $\left|\begin{array}{l}\infty \\
0 \\
0 \\
1\end{array}\right|$ & $\begin{array}{l}0 \\
0 \\
0 \\
1 \\
1 \\
\end{array}$ & 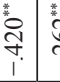 & 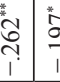 & \\
\hline & ๑ & 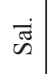 & $\stackrel{T}{2}$ & 3 & 品 & w & 8ิ & రి & & 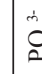 & & & $0^{-1}$ & 范 & \pm & $\nexists$ & 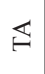 & $\sum^{60}$ & 嗮 & 亿́ & $\dot{z}^{\prime \prime}$ & $=$ & \begin{tabular}{|l|}
0 \\
0 \\
0
\end{tabular} & 索 & 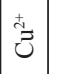 & 索 & 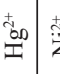 & 势 & \\
\hline
\end{tabular}


level with TH, TA, $\left[\mathrm{Mg}^{2+}\right],\left[\mathrm{Ca}^{2+}\right],\left[\mathrm{Fe}^{2+}\right],\left[\mathrm{Cu}^{2+}\right],\left[\mathrm{Zn}^{2+}\right]$, and negative significance level with DO (Table 2). In this study, the potassium concentration varies between 1.44 and $7.30 \mathrm{mg} \mathrm{L}^{-1}$. The potassium has positive $(\mathrm{r} \geq 0.5)$ significance with; salinity, EC, $\mathrm{SS},\left[\mathrm{SO}_{4}{ }^{2-}\right],\left[\mathrm{SO}_{3}{ }^{2-}\right]$, $\left[\mathrm{Na}^{+}\right], \mathrm{TA},\left[\mathrm{Mg}^{2+}\right],\left[\mathrm{Ca}^{2+}\right],\left[\mathrm{NO}^{2-}\right],\left[\mathrm{NH}_{4}^{+}\right],\left[\mathrm{Fe}^{2+}\right],\left[\mathrm{Pb}^{2+}\right]$, $\left[\mathrm{Cu}^{2+}\right],\left[\mathrm{Hg}^{2+}\right],\left[\mathrm{Ni}^{2+}\right],\left[\mathrm{Zn}^{2+}\right]$ and negative significance relation with DO (Table 2).

The Karaboğaz Stream's TH value varies between 133.32 and $190.24 \mathrm{CaCO}_{3} \mathrm{mg} \mathrm{L}^{-1}$. This parameter has high positive significance $(\mathrm{r} \geq 0.7)$ relation at $\mathrm{P}<0.01$ and $\mathrm{P}<0.05$ significance level with, TA as expected $\left[\mathrm{Mg}^{2+}\right],\left[\mathrm{Ca}^{2+}\right]$ and negative significance relation with DO (Table 2). The total alkalinity (TA) of this study has varied between 139.13 and $195.98 \mathrm{CaCO}_{3} \mathrm{mg} \mathrm{L}^{-1}$. This parameter at $\mathrm{P}<0.01$ and $\mathrm{P}<0.05$ significance level has high positive $(r \geq 0.7)$ significance relation with $\left[\mathrm{Na}^{+}\right]$, $\left[\mathrm{K}^{+}\right], \mathrm{TH}$, and negative significance relation with DO (Table 2).

The magnesium concentration is 9.04 and $10.80 \mathrm{mg} \mathrm{L}{ }^{-1}$. The parameter at $\mathrm{P}<0.01$ and $\mathrm{P}<0.05$ significance level has high positive $(r \geq 0.7)$ significance with $\left[\mathrm{Na}^{+}\right], \quad \mathrm{TH}, \mathrm{TA}$ and $\left[\mathrm{Ca}^{2+}\right]$, and negative significance relation with DO (Table 2). The calcium values have been identified between 9.36 and $12.10 \mathrm{mg}$ $\mathrm{L}^{-1}$. According to Pearson correlation at $\mathrm{P}<0.01$ and $\mathrm{P}<0.05$ significance level, it has high positive $(\mathrm{r} \geq 0.7)$ significance relation with $\left[\mathrm{Na}^{+}\right],\left[\mathrm{K}^{+}\right], \mathrm{TH}, \mathrm{TA},\left[\mathrm{Mg}^{2+}\right]$, $\left[\mathrm{Pb}^{2+}\right],\left[\mathrm{Ni}^{2+}\right],\left[\mathrm{Zn}^{2+}\right]$, and negative significance relation with DO (Table 2).

The nitrite concentration varies between 0.0 and $0.0021 \mathrm{mg} \mathrm{L}^{-1}$. This parameter at $\mathrm{P}<0.01$ and $\mathrm{P}<0.05$ significance level has high positive $(\mathrm{r} \geq 0.7)$ significance relation with salinity, $\mathrm{pH}, \mathrm{WT}, \mathrm{EC}, \mathrm{SS}, \mathrm{COD}, \mathrm{BOD}_{5}$, $\left[\mathrm{PO}_{4}^{3}{ }^{-}\right], \quad\left[\mathrm{SO}_{4}{ }^{2-}\right], \quad\left[\mathrm{SO}_{3}{ }^{2-}\right], \quad \mathrm{K}, \quad\left[\mathrm{NO}_{3}^{-}\right], \quad\left[\mathrm{NH}_{4}^{+}\right]$, and negative significance relation with $\mathrm{DO}$ and $\left[\mathrm{Cl}^{-}\right]$(Table 2). According to nitrite level criteria, this Stream is Class I $\left(\leq 0.01 \mathrm{mg} \mathrm{L}^{-1}\right)[21,22]$. The nitrate concentration varies between 0.0 and $3.90 \mathrm{mg} \mathrm{L}^{-1}$. This parameter at $\mathrm{P}<0.01$ and $\mathrm{P}<0.05$ significance level has high positive $(\mathrm{r} \geq 0.7)$ significance relation with salinity, $\mathrm{pH}$, WT, $\mathrm{EC}, \mathrm{SS}, \mathrm{BOD}_{5}, \mathrm{COD},\left[\mathrm{SO}_{4}{ }^{2-}\right],\left[\mathrm{SO}_{3}{ }^{2-}\right],\left[\mathrm{NO}_{2}^{-}\right],\left[\mathrm{NH}_{4}^{+}\right]$, and negative significance relation with DO and $\left.\mathrm{Cl}^{-}\right]$ (Table 2). This Stream in term of nitrate is classified as Class I $\left(<5 \mathrm{mg} \mathrm{L}^{-1}\right)$ [21, 22].

The ammonium concentration is between 0.0 and $0.0024 \mathrm{mg} \mathrm{L}^{-1}$. This parameter at $\mathrm{P}<0.01$ and $\mathrm{P}<0.05$ significance level has high positive $(r \geq 0.7)$ significance relation with salinity, $\mathrm{pH}, \mathrm{WT}, \mathrm{EC}, \mathrm{SS}, \mathrm{BOD}_{5}$, $\left[\mathrm{PO}_{4}^{3-}\right],\left[\mathrm{SO}_{4}^{2-}\right],\left[\mathrm{SO}_{3}^{2-}\right],\left[\mathrm{NO}_{2}^{-}\right],\left[\mathrm{NO}_{3}^{-}\right]$, and negative significance relation with $\mathrm{DO}$ and $\left[\mathrm{Cl}^{-}\right]$(Table 2). According to the classification criteria of water quality, this stream is class I $\left(<0.2 \mathrm{mg} \mathrm{L}^{-1}\right)$ [21, 22].

Karaboğaz Stream's ferrous level is detected between 0.0010 and $0.0210 \mu \mathrm{g} \mathrm{L}^{-1}$. This parameter at $\mathrm{P}<0.01$ and $\mathrm{P}<0.05$ significance level has high positive $(\mathrm{r} \geq 0.7)$ significance relation with $\left[\mathrm{Na}^{+}\right],\left[\mathrm{Pb}^{2+}\right],\left[\mathrm{Cu}^{2+}\right],\left[\mathrm{Ni}^{2+}\right]$, $\left[\mathrm{Zn}^{2+}\right]$, and negative significance relation with $\mathrm{DO}$ and WT (Table 2). According to the surface water quality criteria of SWQR, this Stream is classified as Class I in terms of ferrous $\left(\leq 300 \mu \mathrm{g} \mathrm{L}^{-1}\right)[21,22]$. The lead level is between 0.20 and $2.80 \mu \mathrm{g} \mathrm{L}^{-1}$. This parameter at $\mathrm{P}<0.01$ and $\mathrm{P}<0.05$ significance level has high positive $(\mathrm{r} \geq 0.7)$ significance relation with $\left[\mathrm{K}^{+}\right],\left[\mathrm{Ca}^{2+}\right],\left[\mathrm{Fe}^{2+}\right],\left[\mathrm{Cu}^{2+}\right]$, $\left[\mathrm{Ni}^{2+}\right],\left[\mathrm{Zn}^{2+}\right]$, and negative significance relation with DO (Table 3). According to SWQR's criteria for surface water quality, Karaboğaz Stream is classified as class I in terms of lead level $\left(\leq 10 \mu \mathrm{g} \mathrm{L}^{-1}\right)$ [21, 22].

The copper level varies between 3.00 and $38.0 \mu \mathrm{g} \mathrm{L} \mathrm{L}^{-1}$. This parameter at $\mathrm{P}<0.01$ and $\mathrm{P}<0.05$ significance level has high positive $(r \geq 0.7)$ significance relation with $\left[\mathrm{Na}^{+}\right],\left[\mathrm{K}^{+}\right],\left[\mathrm{Fe}^{2+}\right],\left[\mathrm{Pb}^{2+}\right],\left[\mathrm{Ni}^{2+}\right],\left[\mathrm{Zn}^{2+}\right]$, and negative significance relation with $\mathrm{DO}$ and WT (Table 2). According to the surface water-quality criteria of SWQR, in terms of copper, this Stream is classified as Class I $\left(\leq 20 \mu \mathrm{g} \mathrm{L}^{-1}\right)$ [21, 22].

Karaboğaz Stream's cadmium level is between 0.0 and $1.70 \mu \mathrm{g} \mathrm{L}^{-1}$. This metal at $\mathrm{P}<0.01$ and $\mathrm{P}<0.05$ significance level has positive $(r \geq 0.6)$ relation with $\mathrm{EC}$, $\mathrm{SS}, \mathrm{COD}, \mathrm{BOD}_{5},\left[\mathrm{SO}_{3}{ }^{2-}\right],\left[\mathrm{NO}_{3}{ }^{-}\right],\left[\mathrm{Hg}^{2+}\right]$, and negative significance relation with DO (Table 2). Karaboğaz Stream is classified as Class I $\left(\leq 2 \mu \mathrm{g} \mathrm{L}^{-1}\right)$ in terms of cadmium $[21,22]$. The mercury level varies between 0.0 and $0.0019 \mu \mathrm{g} \mathrm{L}^{-1}$. This element at $\mathrm{P}<0.01$ and $\mathrm{P}<0.05$ significance level has positive $(\mathrm{r} \geq 0.6)$ significance relation with $\left[\mathrm{Cu}^{2+}\right],\left[\mathrm{Cd}^{2+}\right],\left[\mathrm{Ni}^{2+}\right],\left[\mathrm{Zn}^{2+}\right]$, and negative significance relation with DO and $\left[\mathrm{Cl}^{-}\right]$(Table 2). According to water-quality classification criteria, mercury level is Class I $\left(\leq 0.1 \mu \mathrm{g} \mathrm{L}^{-1}\right)[21,22]$.

In this study, the nickel level is ranged from 3.00 to $13.0 \mu \mathrm{g} \mathrm{L}^{-1}$. This parameter at $\mathrm{P}<0.01$ and $\mathrm{P}<0.05$ significance level has positive $(\mathrm{r} \geq 0.6)$ significance relation with $\left[\mathrm{Na}^{+}\right],\left[\mathrm{K}^{+}\right],\left[\mathrm{Ca}^{2+}\right],\left[\mathrm{Fe}^{2+}\right],\left[\mathrm{Pb}^{2+}\right],\left[\mathrm{Cu}^{2+}\right]$, $\left[\mathrm{Hg}^{2+}\right], \quad\left[\mathrm{Zn}^{2+}\right]$, and negative significance relation with DO (Table 2). According to water-quality classification criteria, nickel level is Class I $\left(\leq 20 \mu \mathrm{g} \mathrm{L}^{-1}\right)$ $[21,22]$.

The zinc level varies between 0.0 and $26.0 \mu \mathrm{g} \mathrm{L}^{-1}$. In this study, zinc value at $\mathrm{P}<0.01$ and $\mathrm{P}<0.05$ significance level has positive $(r \geq 0.6)$ significance relation with $\left[\mathrm{Na}^{+}\right],\left[\mathrm{K}^{+}\right], \mathrm{TA}, \mathrm{TH},\left[\mathrm{Mg}^{2+}\right],\left[\mathrm{Ca}^{2+}\right],\left[\mathrm{Fe}^{2+}\right]$, $\left[\mathrm{Pb}^{2+}\right],\left[\mathrm{Cd}^{2+}\right],\left[\mathrm{Hg}^{2+}\right],\left[\mathrm{Ni}^{2+}\right]$, and negative significance relation with DO (Table 2). According to water-quality classification criteria, zinc level is Class I $\left(\leq 200 \mu \mathrm{g} \mathrm{L}^{-1}\right)$ D [21, 22].

Univariate statistics have the ability to produce definite traits or conclusions for the examined data, but the information obtained in this way is absolutely unilateral and requires a lot of time. Therefore, multivariate statistical methods such as PCA and HCA have been applied to multidimensional datasets created in this study (previously logged and standardised).

Statistical analyses were performed on the data of 120 water samples taken monthly from 10 stations in the Karaboğaz Stream. Based on the mean values of stations and seasons, spatial cluster analysis was applied to 28 parameters and the results are as shown in Fig. 2 and 3. 


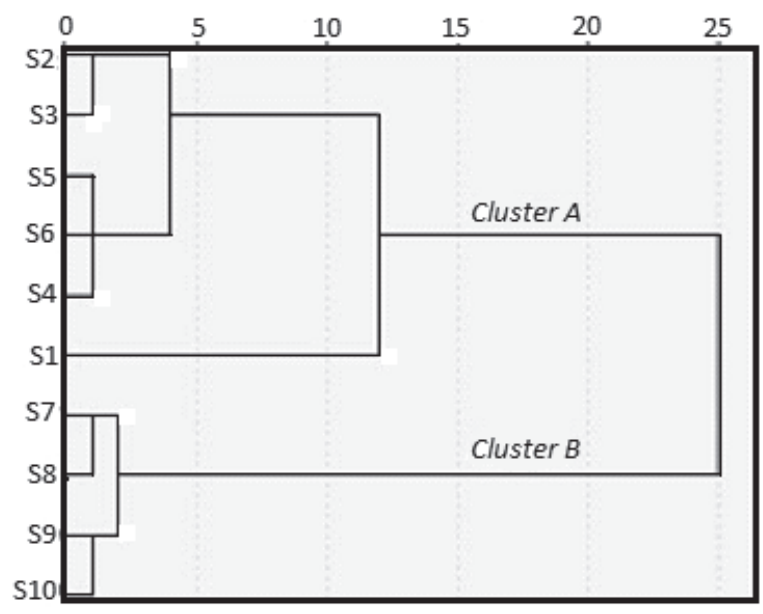

Fig. 2. Dendogram (obtained using the Ward Method) showing clusters of variables (S.:Stations).

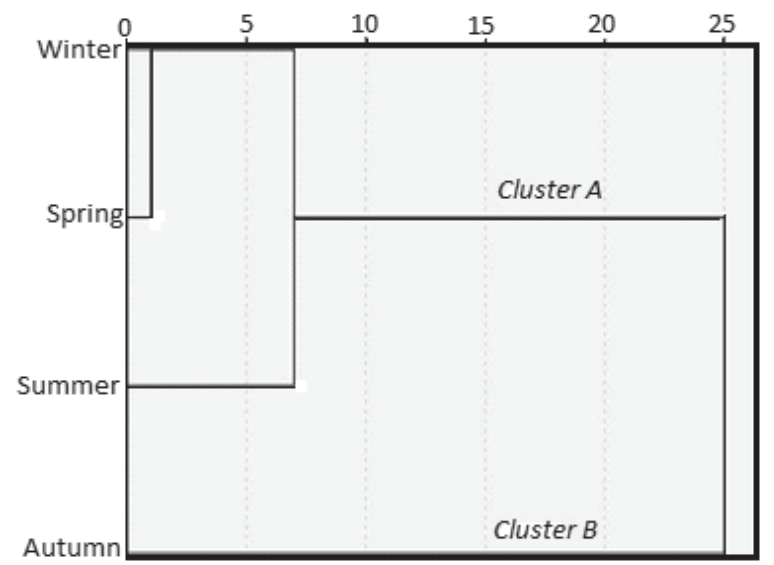

Fig. 3. Dendogram showing clusters of season variables.
Clustering analysis helps to establish spatial similarities between stations [18]. Among the methods applied for the combination of attachment and distance, the best results for the variable relation were obtained using Ward's method and Euclidean distance. Based on the results of the HCA, the parameters are roughly divided into two main groups: clusters A and B. Cluster A comprises S2, S3, S4, S5, S6 and S1 stations, and cluster B comprises S7, S8, S9 and S10 stations. When an internal analysis has been performed to cluster $A$, it has been concluded that $\mathrm{S} 2$ and $\mathrm{S} 3$ as the first group and S4, S5 and S6 as the second group had similar properties in terms of pollution load among themselves, so that the pollutant sources were similar. S1 in cluster A was separated because it was the closest place to the spring, and therefore it is thought that there could be minimum pollutant sources (Fig. 2). Given the internal analysis of cluster $\mathrm{B}$, these are the stations that are located in settlement and agricultural activity areas just before the Karaboğaz Stream joins Frrat River. In this cluster, S7 and S8 stations form the first group and S9 and S10 stations form the second group, and they have similar characteristics among themselves in terms of quality (Fig. 2). According to results of cluster analysis by stations, Karaboğaz Stream has two different water qualities. To assess water quality quickly, it has been shown that a single station in each cluster as well as reduced number of samples could be used for spatial assessment of water quality for the entire network [37].

The temporal clustering analysis was performed using square Euclidean distances as a measure of similarity with standard logged data according to seasons. Based on the results of temporal HCA, groups in terms of seasons have been roughly divided into two main groups: clusters A and B. Cluster A comprises winter, spring and summer seasons, and cluster B

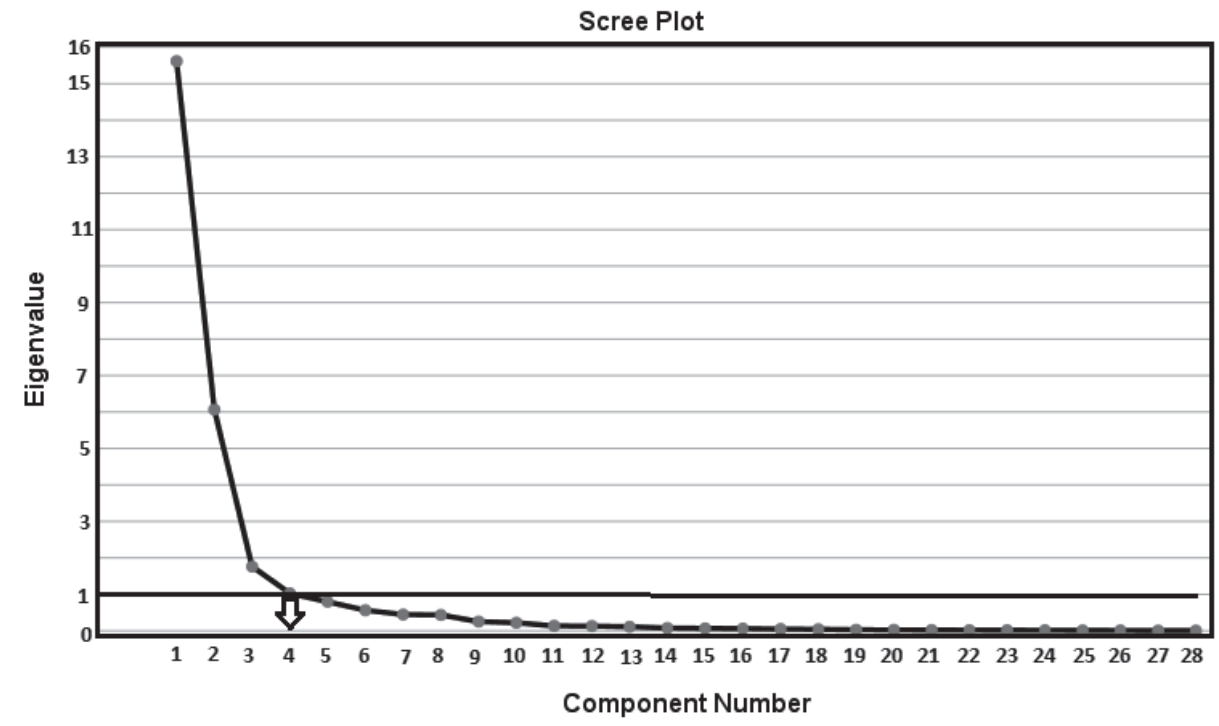

Fig. 4 Component plot. 
Table 3. Varimax rotated factor matrix for the whole data set.

\begin{tabular}{|c|c|c|c|c|}
\hline Variable & PC 1 & PC 2 & PC 3 & PC 4 \\
\hline Eigenvalues & 15.618 & 6.066 & 1.761 & 1.028 \\
\hline Variance $(\%)$ & 55.780 & 21.663 & 6.290 & 3.673 \\
\hline \multirow[t]{2}{*}{ Cumulative (\%) } & 55.780 & 77.444 & 83.734 & 87.407 \\
\hline & \multicolumn{4}{|c|}{ Factor loadings (varimax normalised) } \\
\hline $\mathrm{NO}_{3}^{-}$ & 0.963 & 0.095 & 0.141 & 0.105 \\
\hline WT & 0.951 & -0.073 & 0.188 & -0.091 \\
\hline $\mathrm{BOD}_{5}$ & 0.947 & 0.173 & 0.027 & 0.148 \\
\hline Salinity & 0.930 & 0.154 & 0.082 & 0.147 \\
\hline COD & 0.918 & 0.156 & -0.019 & 0.169 \\
\hline $\mathrm{EC}$ & 0.908 & 0.236 & 0.145 & 0.176 \\
\hline DO & -0.905 & -0.015 & -0.091 & -0.318 \\
\hline $\mathrm{SO}_{3}^{2-}$ & 0.900 & 0.274 & 0.223 & 0.166 \\
\hline SS & 0.898 & 0.330 & 0.135 & 0.149 \\
\hline $\mathrm{SO}_{4}^{2-}$ & 0.851 & 0.300 & 0.355 & 0.027 \\
\hline $\mathrm{pH}$ & 0.840 & -0.018 & 0.284 & 0.183 \\
\hline $\mathrm{NO}_{2}^{-}$ & 0.813 & 0.295 & 0.342 & 0.172 \\
\hline $\mathrm{Cl}^{-}$ & -0.760 & 0.201 & 0.322 & 0.036 \\
\hline $\mathrm{NH}_{4}^{+}$ & 0.714 & 0.282 & 0.452 & 0.062 \\
\hline $\mathrm{Cu}^{2+}$ & -0.008 & 0.913 & 0.170 & 0.268 \\
\hline $\mathrm{Pb}^{2+}$ & 0.262 & 0.912 & 0.157 & -0.061 \\
\hline $\mathrm{Ni}^{2+}$ & 0.186 & 0.883 & 0.124 & 0.165 \\
\hline $\mathrm{Zn}^{2+}$ & 0.151 & 0.856 & 0.321 & 0.052 \\
\hline $\mathrm{Fe}^{2+}$ & 0.006 & 0.849 & 0.246 & 0.148 \\
\hline $\mathrm{Na}^{+}$ & -0.005 & 0.695 & 0.628 & 0.007 \\
\hline $\mathrm{Ca}^{2+}$ & 0.173 & 0.642 & 0.594 & 0.126 \\
\hline $\mathrm{K}^{+}$ & 0.332 & 0.631 & 0.302 & 0.215 \\
\hline $\mathrm{TA}$ & 0.270 & 0.369 & 0.843 & 0.131 \\
\hline $\mathrm{TH}$ & 0.289 & 0.359 & 0.812 & 0.130 \\
\hline $\mathrm{Mg}^{2+}$ & 0.128 & 0.534 & 0.734 & 0.015 \\
\hline $\mathrm{PO}_{4}^{3-}$ & 0.346 & 0.144 & 0.219 & 0.791 \\
\hline $\mathrm{Hg}^{2+}$ & 0.220 & 0.538 & 0.153 & 0.663 \\
\hline $\mathrm{Cd}^{2+}$ & 0.551 & 0.392 & -0.233 & 0.563 \\
\hline
\end{tabular}

comprises only autumn season. When we make an internal analysis of cluster A, it is concluded that the characteristics of winter and spring as the first group are more similar to those of summer. The differences of the summer season from the other two seasons based on the parameters have been demonstrated with the detailed results of the ANOVA variance analysis in Table 1. According to this table in which different letters represent different groups, summer season composes a separate group with respect to other seasons especially with DO, WT, SS, COD, $\mathrm{BOD}_{5},\left[\mathrm{SO}_{3}{ }^{2-}\right], \mathrm{TA},\left[\mathrm{NO}_{2}^{-}\right]$and $\left[\mathrm{NH}_{4}^{+}\right]$parameters. It is not surprising for the summer season to make a difference since these parameters are highly related to temperature. Even though the autumn season forming cluster B is identified as having common features with spring season (Table 1), according to the results of this analysis, it composed a different cluster as seen in Fig. 3. 


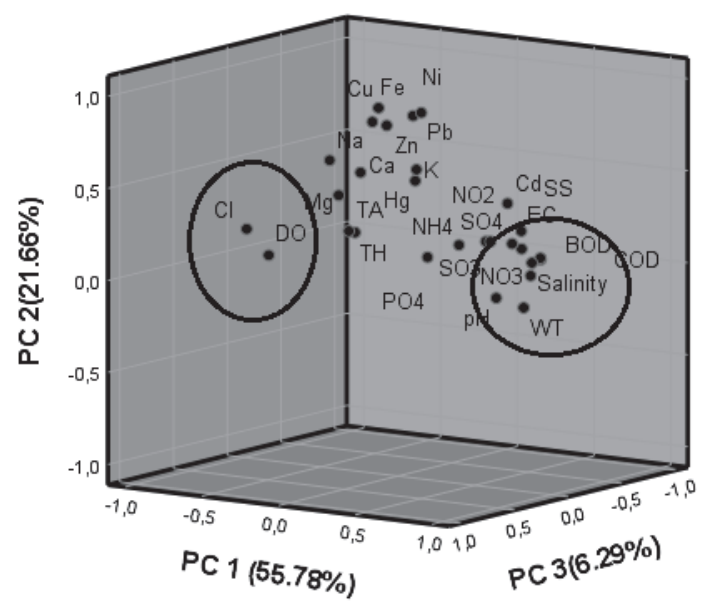

Fig. 5 Scree plot for the principal component model of the monitoring data.

Before applying PCA, the suitability of PCA was initially tested by applying Kaiser-Meyer-Olkin (KMO) and Bartlett tests to data sets. In this study, KMO (equal to 0.89 ) has shown that PCA can provide a significant reduction in the dimensionality of the original data set. In this analysis, 28 physicochemical parameters were classified and finally it is concluded that Karaboğaz Stream's data can be represented by four main components (Table 3). Liu et al. (2003) classified factor loads corresponding to absolute loading values of $0.75,0.75-0.50$ and $0.50-0.30$ as 'strong', 'middle' and 'weak', respectively. In selecting the number of main components, it was supported by incorporating the main components prior to breakage of the Scree plot (Fig. 4) [28, 38, 39].

These main components were obtained with eigenvalues summarising $87.41 \%$ of the total variance in the dataset (Table 3). The first major component explaining $55.78 \%$ of the total variance is strong positive loaded with $\left[\mathrm{NO}_{3}^{-}\right]$, WT, $\mathrm{BOD}_{5}$, salinity, $\mathrm{COD}$, $\mathrm{EC},\left[\mathrm{SO}_{3}{ }^{2-}\right], \mathrm{SS},\left[\mathrm{SO}_{4}{ }^{2-}\right], \mathrm{pH},\left[\mathrm{NO}_{2}^{-}\right]$, moderately positive with $\left[\mathrm{NH}_{4}^{+}\right]$and strong negative with $\mathrm{DO}$ and $\left[\mathrm{Cl}^{-}\right]$ (Table 3 and Fig. 4). This main component represents anthropogenic sources of pollution, physical factors, pollution of organic matter, and the accumulation of soils in the Stream after rainfall spills. This organic factor may be the result of non-point anthropogenic pollution loads of settlement sites, fertilisation used in farming activities (farmers are using nitrogen fertiliser subjected to nitrification), animal feed production, animal husbandry, primary production by algae or as a result microbial activity, increased drainage after rainfalls and natural weather conditions [39]. Chlorine and oxygen, which are thought to be released as a result of the chemical reaction of ozone produced in the stratosphere, also take the same task in natural waters. This master compound contains DO and $\left[\mathrm{Cl}^{-}\right]$that are consumed because of their involvement in biochemical processes and are highly negatively loaded (Table 3 and Fig. 5).
The second major component, constituting 21.66\% of the total variance, has strong positive loading with $\left[\mathrm{Cu}^{2+}\right],\left[\mathrm{Pb}^{2+}\right],\left[\mathrm{Ni}^{2+}\right],\left[\mathrm{Zn}^{2+}\right]$ and $\left[\mathrm{Fe}^{2+}\right]$ (Table 3 and Fig. 5). This factor mainly represents the group of toxic metals. The lack of industry in the region indicates that the sources of these factors exist because of erosion of geological rocks and agricultural activities, which are non-point sources of pollution [40].

The third major component forming 6.29\% of the total variance has high positive loading with PC, TA, TH and $\left[\mathrm{Mg}^{2+}\right]$ (Table 3 and Fig. 4). This factor, represented by the water-hardening parameters, is the result of the dissolution of soluble salts. The source of this group was probably formed by the dissolution of limestone and plaster in the soil and the effect of erosion after rain [39-42].

The fourth PC has the lowest deviation of $3.67 \%$. $\left[\mathrm{PO}_{4}^{3-}\right]$ has strong positive loading (Table 3 and Fig. 5). This factor can be caused by anthropogenic wastes (detergent) from all settlements in the study field without wastewater treatment plant, excessive and ignorant fertiliser usage in agricultural land and phosphorus in soil structure drained via rainfall and mixing with stream water $[8,15,39]$.

\section{Conclusions}

The monthly water-quality data obtained from ten different sampling points representing the whole Stream for 12 months in Karaboğaz Stream were determined primarily according to the water-quality classes of SWQR and WHO standards. Hence, with this study, various multivariate statistical techniques have been used successfully to assess temporal and spatial variation in the quality of Stream's surface water, and to identify the main pollutants and their sources at sampling sites in the study area.

While this Stream mainly represents Class I in terms of water-quality classes, $\left[\mathrm{PO}_{4}^{3-}\right]$ is found to be in Class II, and $\left[\mathrm{Cl}^{-}\right]$and $\left[\mathrm{SO}_{3}{ }^{2-}\right]$ are found to be in Class III. The group, in which sulphide and phosphorus are highly affected in the Pearson correlation, are found to be nitrogen compounds and $\left[\mathrm{Cd}^{2+}\right]$. It is noteworthy that chlorine has a negative relation with these groups. In general, the water quality of the Stream is polluted water. It has been concluded that it can be used in industry after appropriate treatments; however, it does not have the desired properties for the usage of drinking and irrigation water. Heavy metal that could pose a hazard is not detected in this Stream.

Temporal and spatial variability of water quality has been identified with HCA. Because of this test, it has been determined that the autumn season is different from the other seasons. Spatially, the Stream has two different water qualities; stations close to the water source forms one cluster, while the stations close to the area, where Stream joins to the river, forms another cluster. 
Because of the PCA, which is one of the multivariate statistical methods, the four components explain $87.41 \%$ of the total variation. These main components generally reveal most of the changes in water quality as organic pollutants (anthropogenic, non-point and atmospheric air events), heavy metals (toxic metals), soluble salts (natural) and phosphorus that is one of the nutrients (agricultural activity)

The aquatic life, fish life, agriculture and extinct species currently existing in the Karaboğaz Stream continue but in order to improve the existing water quality, the following measures should be taken: the control of excessive and unconscious chemical fertilisers (fruit gardens and other agricultural practices) in the agricultural areas of the region, the prevention of animal wastes reaching the stream water; and also the monitoring surveys should continue. In addition, unconscious and excessive use of agricultural chemicals (fruit gardens and farming practices) that contribute to the degradation of Stream's water quality should be prevented; domestic and animal wastes should be prevented from mixing with the water of Stream without being subject to treatment. In other words, "best environmental practice" principle should be applied to the agricultural activities.

Because of HCA and PCA analysis, which produce the temporal and spatial scale statistic, achievement of similar result from the evaluation of water-quality classes or assessment of environmental hazards confirm that these tests are useful. It can also be applied to interpret complex data sets of water quality, to understand temporal/spatial variation in water quality and to identify hidden pollution sources/factors.

For future water-quality studies, this assessment may be an instrument that can help managers to identify sources of pollution in different regions and to establish priorities for the improvement of water quality in water monitoring plans.

\section{Acknowledgements}

The authors are grateful to all peer reviewers for their reviews and comments.

\section{Conflict of Interest}

The authors declare no conflict of interest.

\section{References}

1. PATIL P.N., SAWANT D.V., DESHMUKH R.N. Physicochemical parameters for testing of water - a review. International Journal of Environmental Sciences, $\mathbf{3}$ (3), 1194, 2012

2. VIALLE C., SABLAYROLLES C., LOVERA M., JACOB S., HUAU M.-C., MONTREJAUD-VIGNOLES M. Monitoring of water quality from roof runoff:
Interpretation using multivariate analysis. Water Research, 45 (12), 3765, 2011.

3. PINFOLD J.V., HORAN N.J., WIROJANAGUD W., MARA D. The bacteriological quality of rain jar water in rural northeast Thailand. Water Research, 27 (2), 297, 1993.

4. LE T.T.H., ZEUNERT S., LORENZ M., MEON G. Multivariate statistical assessment of a polluted river under nitrification inhibition in the tropics. Environmental Science and Pollution Research, 24 (15), 13845, 2017.

5. VEGA M., PARDO R., BARRADO E., DEBAN L. Assessment of seasonal and polluting effects on the quality of river water by exploratory data analysis. Water Research, 32 (12), 3581, 1998.

6. ÖZDEMIR Ö. Application of multivariate statistical methods for water quality assessment of KarasuSarmisakli Streams and Kizilirmak River in Kayseri, Turkey. Polish Journal of Environmental Studies, 25 (3), 1149, 2016.

7. TOKATLI C., KÖSE E., ÇIÇEK A., Assessment of the effects of large borate deposits on surface water quality by multi statistical approaches: a case study of the Seydisuyu stream (Turkey). Polish Journal of Environmental Studies, 23 (5), 1741, 2014.

8. AYDIN UNCUMUSAOĞLU A. Statistical assessment of water quality parameters for pollution source identification in Bektaş Pond (Sinop, Turkey). Global Nest Journal, 20 (1), 151, 2018.

9. KÜKRER S., MUTLU E. Assessment of surface water quality using water quality index and multivariate statistical analyses in Saraydüzü Dam Lake, Turkey. Environmental monitoring and assessment, 191 (2), 71, 2019.

10. USTAOĞLU F. Ecotoxicological risk assessment and source identification of heavy metals in the surface sediments of Çömlekci stream, Giresun, Turkey. Environmental Forensics, 1, 2020.

11. KÖSE E., TOKATLI C., ÇIÇEK A., Monitoring stream water quality: a statistical evaluation. Polish Journal of Environmental Studies, 23 (5), 1637, 2014.

12. JUNG K.Y., LEE K-L., IM T.H, LEE I.J., KİM S., HAN K-Y., AHN J.M. Evaluation of water quality for the Nakdong River Watershed using multivariate analysis. Environmental Technology \& Innovation, 5, 67, 2016.

13. KAUSAR F., QADIR A., AHMAD S.R., BAQAR M. Evaluation of surface water quality on spatiotemporal gradient using multivariate statistical techniques: A case study of river Chenab, Pakistan. Polish Journal of Environmental Studies, 28 (4), 2645, 2019.

14. DIXON W., CHISWELL B. Review of aquatic monitoring program design. Water Research, 30 (9), 1935, 1996.

15. AYDIN UNCUMUSAOĞLU A., AKKAN T. Assessment of Yağlidere stream water quality using multivariate statistical techniques. Polish Journal of Environmental Studies, 26 (4), 1715, 2017.

16. SHRESTHA S., KAZAMA F. Assessment of surface water quality using multivariate statistical techniques: A case study of the Fuji River Basin, Japan. Environmental Modelling and Software, 22 (4), 464, 2007.

17. REGHUNATH R., MURTHY T.R.S., RAGHAVAN B.R. The utility of multivariate statistical techniques in hydrogeochemical studies: an example from Karnataka, India. Water Research, 36, 2437, 2002.

18. SIMEONOV V., STRATIS J.A., SAMARA C., ZACHARIADIS G., VOUTSA D., ANTHEMIDIS A., SOFONIOU M., KOUIMTZIS T. Assessment of the 
surface water quality in Northern Greece. Water Research, 37 (17), 4119, 2003.

19. KAZI T.G., ARAIN M.B., JAMALI M.K., JALBANI N., AFRIDI H.I., SARFRAZ R.A., BAIG J.A., SHAH A.Q. Assessment of water quality of polluted lake using multivariate statistical techniques: A case study, Ecotoxicology and Environmental Safety, 72 (2), 301, 2009.

20. CHAI N., YI X., XIAO J., LIU T., LIU Y., DENG L., JIN Z. Spatiotemporal variations, sources, water quality and health risk assessment of trace elements in the Fen River. Science of the Total Environment, 757, 143882, 2021.

21. WHO. Guidelines for drinking-water quality, fourth edition. WHO. http://www.who.int/water_sanitation health/publications/2011/dwq_guidelines/en/. Accessed $1 \overline{5}$ November 2020.

22. SWQR Turkey's Ministry of Agriculture and Forestry Surface Water Quality Regulations. Number of official gazette: 29797 and 29327, 2016. https://www.resmigazete. gov.tr/eskiler/2016/08/20160810-9.htm (15.11.2020) [In Turkish].

23. Karaboğaz Stream gives life to 10 villages, Memleket gazette https://sivasmemleket.com.tr/gundem/karasukarabogaz-cayi-10-koye-hayat-veriyor-h51546.html. 23 September 2019 [In Turkish].

24. GE J., RAN G., MIAO W., CAO H., WU S., CHENG L. Water quality assessment of Gufu River in three gorges reservoir (China) using multivariable statistical methods. Advance Journal of Food Science and Technology, 5 (7), 908, 2013.

25. APHA Standard Methods for the Examination of Water and Wastewater. 21 $1^{\text {st }}$ Edition, American Public Health Association/American Water Works Association/Water Environment Federation, Washington DC, 2005.

26. ANONYMOUS Standard methods for the examination of water and wastewater. American Public Health Association, 7 th Edition, Washington, USA, 1998.

27. EGEMEN Ö., SUNLU U. Su Kalitesi. Ege Üniversitesi Su Ürünleri Fakültesi. Yayın No:14. E. Ü. Basımevi, Bornova/ İzmir, 1999 [In Turkish].

28. LIU C., LIN K., KUO Y. Application of factor analysis in the assessment of groundwater quality in a Blackfoot Disease area in Taiwan. Science of the Total Environment, 313 (1-3), 77, 2003.

29. ALPAR R. Multivariate statistical methods with applications. Detay Publishing, Ankara, 840, 2017 [In Turkish].

30. YILMAZ ÖZTÜRK B., AKKÖZ C. Investigation of water quality of Apa Dam Lake (Çumra-Konya) and according to the evolution of PCA. Biological Diversity and Conservation, 7 (2), 136, 2014.
31. LEI C., WAGNER P.D., FOHRER N. Effects of land cover, topography, and soil on stream water quality at multiple spatial and seasonal scales in a German lowland catchment. Ecological Indicators, 120, 106940, 2021.

32. MUTLU E., AYDIN UNCUMUSAOGLU A. Investigation of the water quality of Alpsarı Pond (Korgun-Çankır1), Turkish Journal of Fisheries and Aquatic Sciences, 17, 1231, 2017.

33. PARINET B., LHOTE A., LEGUBE B. Principal component analysis: an appropriate tool for water quality evaluation and management application to a tropical lake system. Ecological Modelling, 178, 295, 2004.

34. ANGELlO Z.A., JENS T., BESHAH B.M. SpatioTemporal Evaluation and Quantification of Pollutant Source Contribution in Little Akaki River, Ethiopia: Conjunctive Application of Factor Analysis and Multivariate Receptor Model, Polish Journal of Environmental Studies, 30 (1), 23, 2021.

35. HEROJEET R., RISHI M.S., LATA R., DOLMA K. Quality characterization and pollution source identification of surface water using multivariate statistical techniques, Nalagarh Valley, Himachal Pradesh, India. Applied Water Science, 7 (5), 2137, 2017.

36. MUTLU E., AYDIN UNCUMUSAOĞLU A. Physicochemical analysis of water quality of brook Kuruçay. Turkish Journal of Agriculture, Food Science and Technology, 4 (11), 991, 2016.

37. YURTSEVEN I., RANDHIR T. O. Multivariate assessment of spatial and temporal variations in irrigation water quality in Lake Uluabat watershed of Turkey. Environmental Monitoring and Assessment, 192-793, 2020.

38. HAIR J.F., BLACK W.C., BABIN B.J., ANDERSON R.E. Multivariate data analysis. ISBN-10; 0138132631 | Prentice Hall, Upper Saddle River, 900, 2009.

39. AYDIN UNCUMUSAOGLU A., MUTLU E. Evaluating Spatial and Temporal Variation in Tuzaklı Pond Water Using Multivariate Statistical Analysis. Polish Journal of Environmental Studies, 28 (5), 3861, 2019.

40. MUTLU E. Evaluation of spatio-temporal variations in water quality of Zerveli stream (northern Turkey) based on water quality index and multivariate statistical analyses. Environmental monitoring and assessment, 191 (6), 335, 2019.

41. VEREP B., TAŞPINAR ÖLMEZ B., MUTLU C. Investigation of bacteriological and detergent-based pollution in the Salarha Basin Rivers. Journal of Anatolian Environmental and Animal Sciences, 4 (3), 565, 2019.

42. BILGIN YILDIRIM H. Heavy metals in freshwater ecosystems, Ankara, 128. 2016. [In Turkish]. 